\title{
Comparison of the CMAM30 data set with ACE-FTS and OSIRIS: polar regions
}

\author{
D. Pendlebury ${ }^{1}$, D. Plummer ${ }^{2}$, J. Scinocca ${ }^{2}$, P. Sheese ${ }^{1}$, K. Strong ${ }^{1}$, K. Walker ${ }^{1,3}$, and D. Degenstein ${ }^{4}$ \\ ${ }^{1}$ Department of Physics, University of Toronto, Toronto, Canada \\ ${ }^{2}$ Canadian Centre for Climate Modelling and Analysis, Victoria, Canada \\ ${ }^{3}$ Department of Chemistry, University of Waterloo, Waterloo, Canada \\ ${ }^{4}$ Department of Physics and Engineering Physics, University of Saskatchewan, Saskatoon, Canada \\ Correspondence to: D. Pendlebury (diane@atmosp.physics.utoronto.ca)
}

Received: 1 March 2015 - Published in Atmos. Chem. Phys. Discuss.: 16 April 2015

Revised: 28 July 2015 - Accepted: 17 August 2015 - Published: 10 November 2015

\begin{abstract}
CMAM30 is a 30-year data set extending from 1979 to 2010 that is generated using a version of the Canadian Middle Atmosphere Model (CMAM) in which the winds and temperatures are relaxed to the Interim Reanalysis product from the European Centre for Medium-Range Weather Forecasts (ERA-Interim). The data set has dynamical fields that are very close to the reanalysis below $1 \mathrm{hPa}$ and chemical tracers that are self-consistent with respect to the model winds and temperature. The chemical tracers are expected to be close to actual observations. The data set is here compared to two satellite records - the Atmospheric Chemistry Experiment Fourier transform spectrometer and the Odin Optical Spectrograph and Infrared Imaging System - for the purpose of validating the temperature, ozone, water vapour and methane fields. Data from the Aura microwave limb sounder are also used for validation of the chemical processing in the polar vortex. It is found that the CMAM30 temperature is warmer by up to $5 \mathrm{~K}$ in the stratosphere, with a low bias in the mesosphere of $\sim 5-15 \mathrm{~K}$. Ozone is reasonable $( \pm 15 \%)$, except near the tropopause globally and in the Southern Hemisphere winter polar vortex. Water vapour is consistently low by 10-20\%, with corresponding high methane of 10-20\%, except in the Southern Hemisphere polar vortex. Discrepancies in this region are shown to stem from the treatment of polar stratospheric cloud formation in the model.
\end{abstract}

\section{Introduction}

Reanalysis data sets such as those used in this study (the European Centre for Medium-Range Weather Forecasts (ECMWF) Reanalysis Interim product, or ERA-Interim) are the result of high-resolution models that assimilate past measurements to produce a consistent product that is a reliable representation of the atmospheric state over a given time period. However, while dynamical fields, water vapour (or specific humidity) and ozone are provided by the reanalysis, other species are not. In addition, while the reanalysis models employ sophisticated physical schemes for some processes (such as land-surface interaction and convection), they have very basic chemistry schemes (e.g. Dee et al., 2011) and generally do not include physical processes that are necessary for an accurate representation of the stratosphere and mesosphere, such as gravity wave momentum deposition. Chemistry-climate models (CCMs) with full interactive chemistry are capable of modelling many of these atmospheric processes but cannot be compared directly to observations since they are not expected to capture the true dayto-day variability of the atmosphere. The CMAM30 data set, based on the Canadian Middle Atmosphere Model (CMAM), bridges this gap by using a fully interactive CCM but with the dynamical fields "nudged" (relaxed) to ERA-Interim values. By construction, the CMAM30 data set should capture the correct daily, seasonal and interannual variability of the winds and temperatures below $1 \mathrm{hPa}$, while providing trace gas information that is consistent with those fields. In addition, data sets such as CMAM30 that use specified dynamics 
can be used to isolate deficiencies in physical parameterizations in the underlying model (e.g. Brakebusch et al., 2013).

There are several limitations to this approach. First, the model has a relatively coarse spatial resolution and should therefore not be expected to reproduce small-scale structures. Even structures on the finest model scales will be heavily damped by the model diffusion. For example, structures related to cross-tropopause transport such as tropopause folds and mixing, even by planetary-scale waves, would be difficult to reproduce exactly. Other differences between the CMAM30 data set and observations may arise because while the large-scale dynamical fields are constrained to be close to ERA-Interim winds and temperatures, the chemical fields evolve according to the model chemistry, and small-scale dynamics and the physical parameterizations that mimic the subscale behaviour can affect even the large-scale dynamical fields. Several recent papers have validated several aspects of CMAM30 but in a limited context. McLandress et al. (2013) compared CMAM30 polar cap mesospheric temperatures and midlatitude mean zonal winds to data from the microwave limb sounder instrument on-board the Aura satellite for the extended northern winters of 2005/06 and 2008/09 and found good agreement. Hegglin et al. (2014) and Shepherd et al. (2014) used CMAM30 water vapour and ozone in order to make better sense of the long-term observational records of these species. However, the comparisons of CMAM30 data to observations made in these papers are limited in their extent. It is therefore necessary to provide a more complete validation of the chemical and dynamical fields from the CMAM30 data set.

To accomplish this task, data from the Atmospheric Chemistry Experiment Fourier transform spectrometer (ACE-FTS) instrument on-board the ACE satellite, the Optical Spectrograph and Infrared Imaging System (OSIRIS) on-board the Odin satellite, and the microwave limb sounder instrument on-board the Aura satellite (Aura-MLS) are used. In this paper, the focus is on temperature, ozone, water vapour and methane. Here, we will compare coincident profiles from the satellites and the CMAM30 data set to establish the reliability of the model over the satellite period by looking at the median biases and median deviation about the biases. Essentially, the CMAM30 data is subsampled in approximately the same way that the satellite instruments "see" the atmosphere, avoiding errors due to differences between using the full model grid and the subsampling of the atmosphere by the satellite instruments (see Toohey and von Clarmann, 2013, for more details). Special attention will be given to regions and time periods where the model bias is greater, to examine possible causes for the discrepancies. In addition, the polar vortex chemical processing will be compared for two winters - a typical Southern Hemisphere (SH) winter and a cold Northern Hemisphere $(\mathrm{NH})$ winter - to investigate the treatment of polar stratospheric clouds and their effect on ozone in the model.
The paper is structured as follows: Sect. 2 briefly describes the model and the specification of the model dynamics, and Sect. 3 describes the observational data used. Section 4 describes the results, outlining the method used for the profile comparisons, with particular focus on the polar regions. A separate paper focusing on the tropical region and the Brewer-Dobson circulation is forthcoming. Section 5 summarizes the results.

\section{Model}

The CMAM is a comprehensive chemistry-climate model with T47 spectral resolution $\left(3.75^{\circ} \times 3.75^{\circ}\right)$ and 71 vertical levels up to $0.01 \mathrm{hPa}$ ( $~ 98 \mathrm{~km}$ altitude). The CMAM30 data set uses the ERA-Interim products to nudge the temperature and winds (through vorticity and divergence) on large spatial scales $(<\mathrm{T} 21)$ with a Newtonian relaxation timescale of $24 \mathrm{~h}$. ERA-Interim data are available up to $1 \mathrm{hPa}$, although the atmospheric model used in the reanalysis had a model lid at $0.1 \mathrm{hPa}$ (Dee et al., 2011). The nudging of CMAM is applied at full strength up to $1 \mathrm{hPa}$, as no significant artefacts were found by abruptly stopping the application of nudging at this level. However, the ERA-Interim data set does contain a number of significant discontinuities in temperature on levels at and above $5 \mathrm{hPa}$ associated with changes in the assimilated satellite temperature sounders, as these are the only source of temperature data at these altitudes (Dee and Uppala, 2009). To avoid introducing spurious trends into the CMAM simulation, the global-average temperatures in the ERA-Interim data for levels at $5 \mathrm{hPa}$ and above were modified before being used in the nudging following the method described in McLandress et al. (2014). As the CMAM is known to have good representation of the upper stratosphere and lower mesosphere (e.g. Fomichev et al., 2007) and because the general behaviour of the mesosphere is slaved to the stratosphere (Nezlin et al., 2009), the day-to-day evolution of the region above $1 \mathrm{hPa}$ is not expected to deviate greatly from reality. The CMAM30 is sampled every $6 \mathrm{~h}$ with data interpolated to a set of 63 constant pressure surfaces, chosen to be close to the underlying model levels above $100 \mathrm{hPa}$. For more details on the CMAM see Scinocca et al. (2008), and on the CMAM30 data set, see McLandress et al. (2014) and Shepherd et al. (2014).

Of particular importance to the work presented here is the treatment of polar stratospheric clouds (PSCs) in the model. PSCs form when the thermodynamic and chemical conditions in the atmosphere are appropriate (generally when the temperature dips below $196 \mathrm{~K}$ for Type 1 PSCs, which are composed of nitric acid, sulfuric acid and water, and below $188 \mathrm{~K}$ for Type 2 PSCs, which are solid water (Peter, 1997)). PSCs are important for ozone depletion in the polar vortex during spring for two reasons: firstly, heterogeneous reactions take place on PSC surfaces converting chlorine reservoirs to reactive chlorine, and secondly, the sedimentation of 
the large ice particles containing $\mathrm{HNO}_{3}$ produces denitrification of the lower-stratosphere polar vortex, preventing the replenishment of the chlorine reservoir $\mathrm{ClONO}_{2}$.

In the CMAM, the abundance of stratospheric ternary solution PSCs, often referred to as Type $1 \mathrm{~b}$, is calculated following Carslaw et al. (1995). Water ice particles, Type 2 PSCs, are based on a condition requiring a $40 \%$ supersaturation with respect to the frost point (Considine et al., 2000). Solid nitric acid trihydrate (NAT) PSC particles are not accounted for in the CMAM PSC scheme. The equilibriumbased calculation of PSCs sequesters $\mathrm{HNO}_{3}$ and water in the aerosol phase, although the model does not account for sedimentation of the solid particles regardless of how long they persist. Therefore, denitrification or dehydration of the polar vortex over the winter season does not occur, with $\mathrm{HNO}_{3}$ and water vapour returning to the gas phase based on thermodynamic equilibrium.

\section{Observations}

The primary observational data used here are from the ACEFTS and OSIRIS instruments. Since OSIRIS measurements include only ozone and temperature relevant to this study, and since ACE-FTS measurements are spatially sparse with gaps in certain months due to the nature of its polar orbit and solar occultation viewing geometry, Aura-MLS measurements, which are spatially denser than ACE-FTS and provide more constituents than OSIRIS, are used when necessary.

\subsection{OSIRIS data}

The Odin satellite was launched in February 2001 and has a sun-synchronous orbit with an ascending node of $\sim 18: 00$ local time. The OSIRIS instrument operates between 280 and $810 \mathrm{~nm}$, observing Rayleigh- and Mie-scattered sunlight and airglow emissions in the Earth's limb (Llewellyn et al., 2004). OSIRIS measures a vertical radiance profile by scanning a single line of sight from the upper troposphere $(\sim 7 \mathrm{~km})$ to the mid- to upper mesosphere $(65-$ $90 \mathrm{~km})$. OSIRIS has an instantaneous $1 \mathrm{~km}$ vertical field of view, and this, along with the scanning, results in retrieved profiles that have a vertical resolution of approximately $1.5 \mathrm{~km}$. During each orbit, 30-60 vertical scans are made, with a focus on the NH during March to September and on the SH during October to February. Near-global coverage $\left(82^{\circ} \mathrm{S}\right.$ to $\left.82^{\circ} \mathrm{N}\right)$ is achieved in October and February due to the change in orbital geometry.

The OSIRIS data used here are ozone volume mixing ratios included in the OSIRIS level 2 v5.07 data set from January 2002 to December 2010 (Degenstein et al., 2009). Validation of v5.07 with SAGE (Stratospheric Aerosol and Gas Experiment) II for 2001 to 2005 can be found in Adams et al. (2013), with agreement generally within $5 \%$ below $50 \mathrm{~km}$, and with multiple data sets in Adams et al. (2014). Note that the temperatures provided with the OSIRIS level 2 data are not actually retrieved values but are taken from ECMWF operational analyses. A comparison with these temperatures is therefore not included here. Instead, OSIRIS temperatures derived from the $\mathrm{O}_{2}$ A-band emission spectra near $762 \mathrm{~nm}$ (see Sheese et al., 2010, 2012, for details) are used. Temperature data are available between 45 and $110 \mathrm{~km}$, but temperatures between 80 and $86 \mathrm{~km}$ are deemed unreliable, due to uncertainties in $\mathrm{O}_{2}$ absorption in the A-band. The temperature data also exhibit a cold bias of $10-15 \mathrm{~K}$ near $85 \mathrm{~km}$ (Sheese et al., 2011) (the upper boundary of the Rayleighscatter-derived temperatures) and a cold bias of 5-15 K near $48 \mathrm{~km}$ due to multiple scattering effects not taken into account in the retrieval. However, between 55 and $80 \mathrm{~km}$, these temperatures are valid and are typically within $4-5 \mathrm{~K}$ of other satellite data (Sheese et al., 2012).

\subsection{ACE-FTS data}

The ACE-FTS is a high spectral resolution $\left(0.02 \mathrm{~cm}^{-1}\right)$ solar occultation instrument, operating in the spectral range of $750-4400 \mathrm{~cm}^{-1}$, that derives vertical profiles of temperature and concentrations of a number of species related to ozone chemistry (Bernath et al., 2005; Boone et al., 2005), including ozone, water vapour, and methane. Since the ACE mission was designed primarily to observe the Earth's atmosphere at high latitudes, the orbit does not measure at all latitudes in all months. Instead, the orbit allows for measurements at high latitudes for much of the year, crossing the terminator during February, April, August and October. For each day, up to 15 sunrise and 15 sunset profiles are available, with a vertical resolution of 3-4 km throughout the upper troposphere to the lower thermosphere. The satellite was launched in August 2003 and has been providing measurements since February 2004. Profiles up to December 2010 are used here.

In this study, the $1 \mathrm{~km}$ vertical gridded data from ACEFTS level 2 v3.5 are used (Boone et al., 2013). Version 2.2 temperature, ozone and methane were validated by Sica et al. (2008), Dupuy et al. (2009), and de Maziére et al. (2008), respectively, and water vapour has been compared to other instruments using a climatological approach by Hegglin et al. (2013). Comparisons between v2.2 and v3.0/3.5 trace gas data sets are described by Waymark et al. (2013), with some small changes from v3.0 and v3.5. In addition to the measurements, corresponding derived meteorological products (DMPs) calculated from the GEOS5 (Goddard Earth Observing System model, version 5) data assimilation system are also available for each ACE-FTS occultation (see Manney et al., 2007). The scaled potential vorticity (sPV) is used to determine whether an ACE-FTS profile is inside or outside the polar vortex (see Manney et al., 2007, for a discussion of sPV). For the evaluation of the chemical processing of the polar vortex, $\mathrm{HCl}$ (Mahieu et al., 2008), $\mathrm{ClONO}_{2}$ and $\mathrm{HNO}_{3}$ 
(Wolff et al., 2008) are also used to diagnose the representation of PSCs in the CMAM.

\subsection{Aura-MLS data}

For the evaluation of the chemical processing of the winter polar vortex, Aura-MLS data are included. Like OSIRIS, the Aura microwave limb sounder scans the Earth's atmosphere in the limb from the surface to $90 \mathrm{~km}$, providing nearglobal coverage from $82^{\circ} \mathrm{N}$ to $82^{\circ} \mathrm{S}$, daily. It measures thermal emissions at submillimetre and millimetre wavelengths. The Aura satellite was launched in July 2004, but only data from January to April 2005 and July to December 2006 are used here. Version 3.3/3.4 of the data set has been used in this study. The validation of the species used in this study for version 2.2 of the Aura-MLS data set can be found in Froidevaux et al. (2008a) for $\mathrm{HCl}$, Santee et al. (2008a) for ClO, Lambert et al. (2007) for $\mathrm{H}_{2} \mathrm{O}$, Froidevaux et al. (2008b) for $\mathrm{O}_{3}$, Santee et al. (2007) for $\mathrm{HNO}_{3}$, and Schwartz et al. (2008) for temperature; see also Livesey et al. (2013). The Aura-MLS observations also provide corresponding DMPs calculated from MERRA (Modern-Era Retrospective analysis for Research and Applications) for sPV to determine the position of the polar vortex (see Manney et al., 2007).

\section{Results}

A coincident profile approach to comparisons between the CMAM30 data set and observational data is taken here. In order to make use of as many profiles as possible, the model data are interpolated to the time and tangent-height location of each profile measurement for both instruments (tangent heights for ACE-FTS and OSIRIS are 30 and $25 \mathrm{~km}$, respectively). Since the measurements are actually taken through a slant column of the atmosphere rather than at a single geolocation, this approach introduces some error into the analysis. The slant path error may be an issue for ACE-FTS measurements when smaller scales are present, at higher altitudes (i.e. far from the tangent height), and for high beta angles. Beta angles for ACE-FTS are typically less than $50^{\circ}$ from the zenith, with $13 \%$ of measurements taken at beta angles between $50^{\circ}$ and $65^{\circ}$. These profiles are taken at lower latitudes and when the satellite orbit crosses the equator. For calculating differences, all observational data are interpolated onto the CMAM30 pressure levels except for the OSIRIS temperatures derived from the $\mathrm{O}_{2}$ A-band. Because only polar vortex averages are compared, there is no need for interpolation of the CMAM30 data to the location of each profile.

For a spatial picture (latitude by height cross section), the results are binned by latitude $\left(5^{\circ}\right)$ and zonally and monthly averaged. For time series, the results are binned by $30^{\circ}$ latitude and zonally averaged. For each species and temperature profile, the median model bias (CMAM30 - satellite), and the relative difference from the satellite ((CMAM30- satellite)/satellite) is calculated, and then the mean absolute deviation (MAD) is calculated for each bin. The median is used instead of the mean since it is not adversely affected by extreme outliers in the satellite data that are not removed using the data quality flags. In most cases here, there is no discernible difference between the mean and median values for bias. The MAD, defined as

$\operatorname{MAD}\left(x_{i}\right)=\operatorname{Median}\left|x_{i}-\operatorname{Median}(x)\right|$,

is used here as a measure of variability instead of the standard deviation since it is robust against statistical problems related to small sample size (e.g. Rousseeuw and Croux, 1993). $|(\cdot)|$ is the absolute value of $(\cdot)$.

Section 4.1 details the overall median bias of the CMAM30 data set and the MAD contours for both the spatial and time series results. In Sect. 4.2, we focus on the late winter and spring southern polar vortex in the stratosphere, where the CMAM30 shows particularly large disagreement with respect to both the ACE-FTS and OSIRIS measurements, and use a polar vortex average over the winter and spring to examine the dehydration of the vortex and ozone destruction. Aura-MLS observations are included here in order to further examine chemical processing in the lowerstratosphere polar vortex. In Sect. 4.3, we focus on an NH winter with a stratospheric sudden warming (SSW) to determine the reliability of the CMAM30 data set during a dynamically active time period, and we also use polar vortex averaging during a winter with no SSW to examine the effect of the PSC treatment during $\mathrm{NH}$ winters.

\subsection{Coincident profile comparisons}

Results are shown in Figs. 1 and 2 for OSIRIS temperature (derived from the $\mathrm{O}_{2}$ A-band) and ozone, respectively, for January, April, July and October from January 2002 through October 2010. Figures 3 to 6 show results for ACE-FTS temperature, ozone, water vapour, and methane for the same months for February 2004 to 2010. These months are chosen to be representative of the seasons but are short enough time periods to prevent obscuring differences between the model and the observations. Note that the colour scheme is chosen to show high bias in CMAM30 as yellows and reds and low bias as blues.

Comparisons with the retrieved OSIRIS temperatures of Sheese et al. (2010) show a low bias in the model of $\sim 10 \mathrm{~K}$, below $85 \mathrm{~km}$ (see Fig. 1). Note that the OSIRIS temperatures are shown as a function of altitude and only above $55 \mathrm{~km}$, above the region of nudging for the model. CMAM30 temperatures are compared using geopotential height as the altitude. Above $85 \mathrm{~km}$, the CMAM30 temperatures show a high bias of up to $20 \mathrm{~K}$ during summer months (NH July and SH January), although Sheese et al. (2011) point out that above $85 \mathrm{~km}$ the retrieved temperatures from OSIRIS themselves indicate a low bias of $10-15 \mathrm{~K}$ in comparison to data from SABER on TIMED (Sounding of the Atmosphere 
(a) CMAM30 - OSIRIS Jan 2002-2010

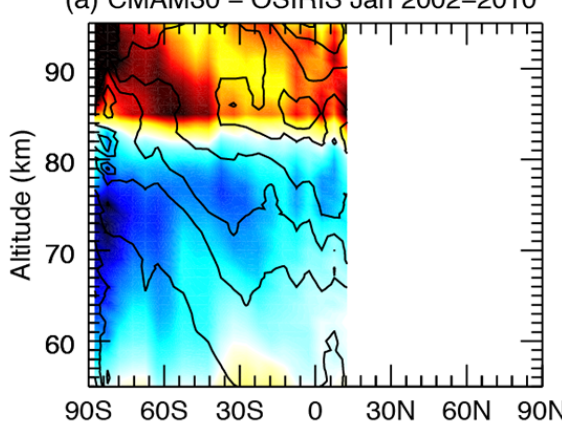

(c) CMAM30 - OSIRIS Jul 2002-2010
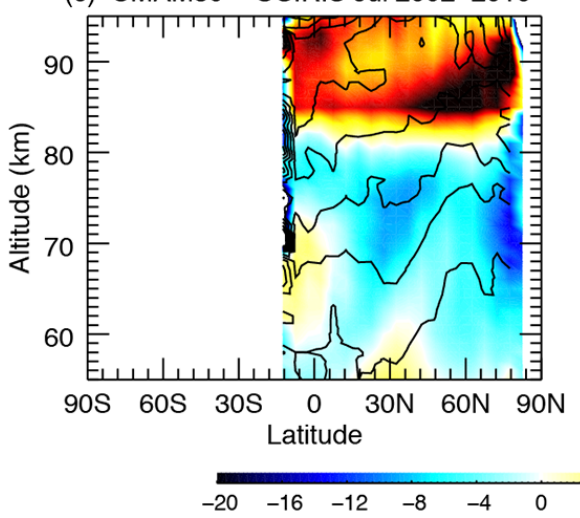

(b) CMAM30 - OSIRIS Apr 2002-2010

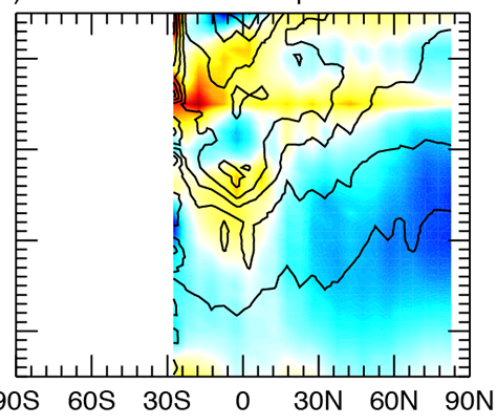

(d) CMAM30 - OSIRIS Oct 2002-2010

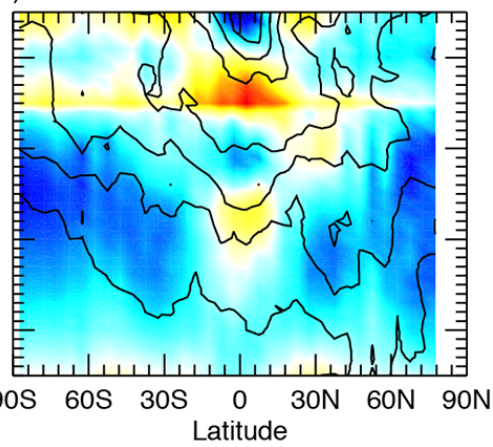

Figure 1. Absolute temperature differences for CMAM30 vs. OSIRIS profiles, derived from the $\mathrm{O}_{2}$ A-band. Shown are averages over the entire time period for January (a), April (b), July (c) and October (d). The median temperature difference is shown by the colour scale and the contours indicate the MAD with contour intervals of $2 \mathrm{~K}$. Reds indicate where CMAM30 has a warm bias compared with observations, and blues indicate where CMAM30 has a cold bias.

using Broadband Emission Radiometry on Thermosphere Ionosphere Mesosphere Energetics Dynamics) and SOFIE on AIM (Solar Occultation For Ice Experiment on Aeronomy of Ice in the Mesosphere), indicating that the CMAM30 high bias in the upper altitude region is closer to 5-10 K compared to those satellites. This large discrepancy is not seen in the ACE-FTS temperature comparisons (see Fig. 3). Note that the largest biases are near $85 \mathrm{~km}$, where OSIRIS temperatures are known to be problematic.

Comparisons with ACE-FTS show that overall, much of the stratosphere in CMAM30 is slightly warm on average throughout the year, while the mesosphere (above $1 \mathrm{hPa}$ ) is cooler than the measurements (see Fig. 3). Above $1 \mathrm{hPa}$, CMAM30 exhibits a cold bias of up to $12-15 \mathrm{~K}$ compared to ACE-FTS, associated with high variability where median temperatures deviate more than $\pm 10 \mathrm{~K}$. (Note that high MAD may indicate high variability, small sample size, or both.) The CMAM30 temperature comparison agrees with the results from OSIRIS (see above) if the cold bias in OSIRIS temperatures above $85 \mathrm{~km}$ is taken into account. Of particular note is the cold bias in SH winter (July) and autumn (April) in the lower mesosphere and the warm bias in the upper mesosphere, which is most apparent in July. This vertical dipole structure, which can also be seen in SH sum- mer, is the result of insufficient gravity wave drag in the model stratosphere and lower mesosphere. Below $1 \mathrm{hPa}$, the winds are constrained by the ERA-Interim winds, but above this level the winds take on the climatological structure of the free-running model, which is characterized by too strong a SH winter westerly jet; a manifestation of the so-called "cold pole problem" common to most CCMs (SPARC CCMVal, 2010). The warm bias in the SH upper mesosphere in CMAM30 is due to too strong non-orographic gravity wave drag in the upper mesosphere that results from filtering by the too strong lower-mesospheric westerlies. An example of this phenomenon, but for the case of NH winter, is seen in Fig. 5 of McLandress et al. (2013) in their simulation of the CMAM in which the orographic gravity wave drag was turned off.

Comparisons with ozone (Figs. 2 and 4) show that most of the CMAM30 stratosphere is within $\pm 10 \%$ of the measurements. Agreement in the lowermost extratropical stratosphere, particularly in the SH, and the tropical lower stratosphere is not particularly good, with large, mostly positive biases in the CMAM30. In this region, the ozone mixing ratio is relatively small and so even absolute differences of only $0.1 \mathrm{ppmv}$ may lead to large relative differences. In addition, it is a region of high variability due to isentropic transport of tropical tropospheric air poleward and extratropical 
(a) CMAM30 - OSIRIS Jan 2002-2010

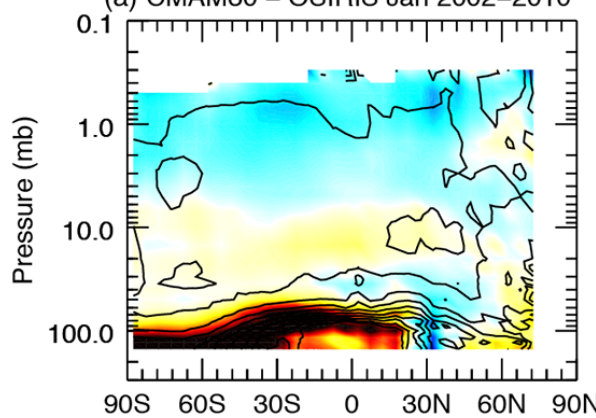

(c) CMAM30 - OSIRIS Jul 2002-2010

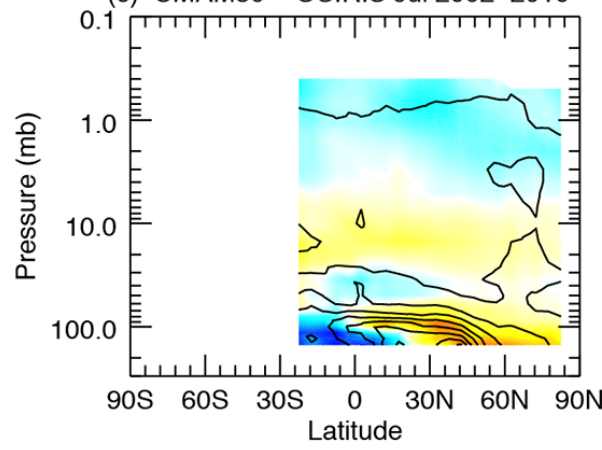

(b) CMAM30 - OSIRIS Apr 2002-2010

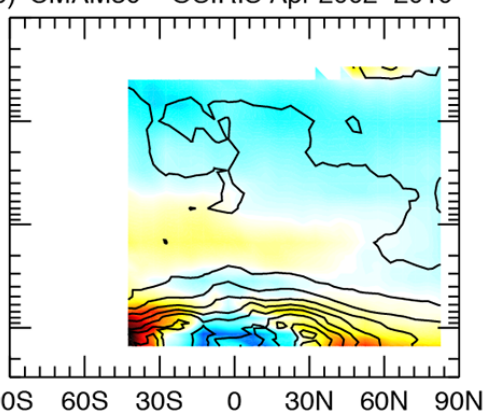

(d) CMAM30 - OSIRIS Oct 2002-2010

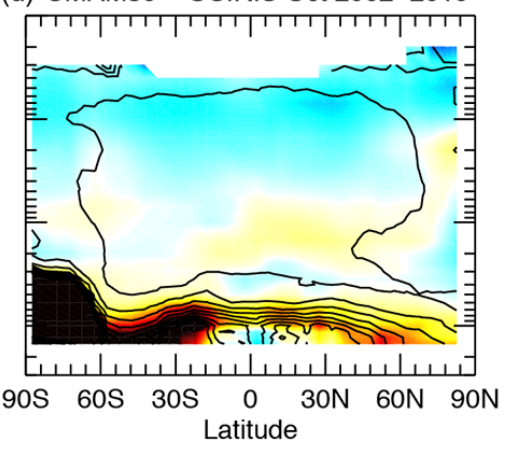

$\begin{array}{rllllllllll}-50 & -40 & -30 & -20 & -10 & 0 & 10 & 20 & 30 & 40 & 50\end{array}$

Figure 2. Same as Fig. 1 but for CMAM30 vs. OSIRIS relative differences for ozone profiles. MAD contour levels are $5 \%$. Reds indicate where CMAM30 ozone is too high compared to OSIRIS, and blues indicate where CMAM30 ozone is low. Note that the vertical axis here is pressure.

lower-stratospheric air equatorward and a region of sharp vertical gradients that are not well resolved by the model that may cause the tropopause in the model to be too low in altitude. Note that the ozone is almost uniformly higher in CMAM30 compared to OSIRIS by more than $50 \%$ near and below $100 \mathrm{hPa}$. Of particular interest is the springtime (October) SH polar lower stratosphere, where CMAM30 shows considerable disagreement with OSIRIS (Fig. 2d). Note that compared to ACE-FTS, CMAM30 shows a low bias in the upper troposphere and/or lower stratosphere in the tropics (see Fig. 4) in October, in contrast to the OSIRIS data, and a larger, more negative bias in April. Above $10 \mathrm{hPa}, \mathrm{CMAM} 30$ shows a low bias in ozone compared to both satellite data sets, related to the decrease in altitude of the ozone profile; CMAM30 profiles generally decrease too rapidly above the ozone maximum. At $0.1 \mathrm{hPa}$, the diurnal cycle of ozone becomes important in the comparisons, and while ACE-FTS ozone profiles extend to this altitude, they have not been validated above $70 \mathrm{~km}$ (Dupuy et al., 2009).

Comparisons with ACE-FTS water vapour (see Fig. 5) show that CMAM30 has an overall low bias of approximately 10-20\% throughout the stratosphere. The low bias is a well-known deficiency of the CMAM model (SPARC CCMVal, 2010), but it is interesting to see that it persists even with specified dynamics. Figure 5 indicates that the low bias is more pronounced just above the tropical tropopause, and therefore may be due to too much dehydration of the air entering the stratosphere through the tropical tropopause layer. Aside from this persistent low bias, the behaviour of water vapour throughout the stratosphere is otherwise reasonable, i.e. there is little variability in the difference between CMAM30 and ACE-FTS. Most of the variability occurs in the vicinity of the tropopause, except in the wintertime (July) southern polar vortex, where the bias in CMAM30 water vapour becomes close to 0 and even positive. This feature is explored below.

Figure 6 shows that, over much of the stratosphere, methane has a high bias in the CMAM30 compared to the ACE-FTS bias of 10-20\%. The fact that water vapour is consistently low and methane consistently high may indicate that there is not enough production of water vapour through the oxidation of methane, consistent with a fast Brewer-Dobson circulation. Note that although there are regions of large discrepancy between CMAM30 methane and ACE-FTS measurements at high latitudes that appear to propagate downward over the course of a few months, these discrepancies are likely a problem of vertical resolution in the model. The methane profiles exhibit a kink between 10 and $1 \mathrm{hPa}$ in both the model and the ACE-FTS observations. Such a kink is also seen in both the HALOE (HALogen Occultation Ex- 


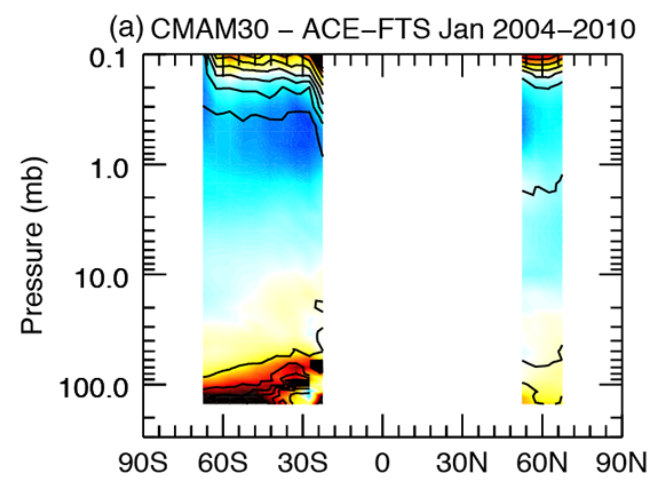

(b) СMАМЗ0 - ACE-FTS Apr 2004-2010

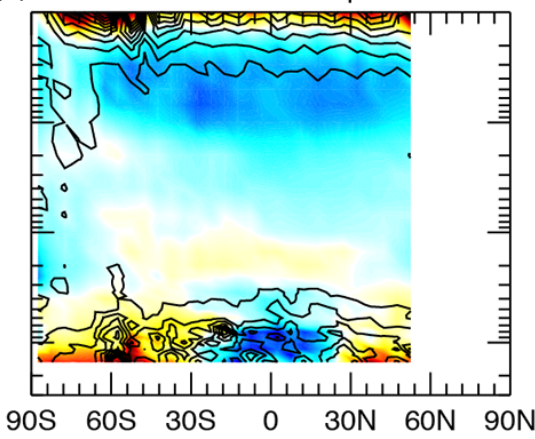

(c) CMAM30 - ACE-FTS Jul 2004-2010

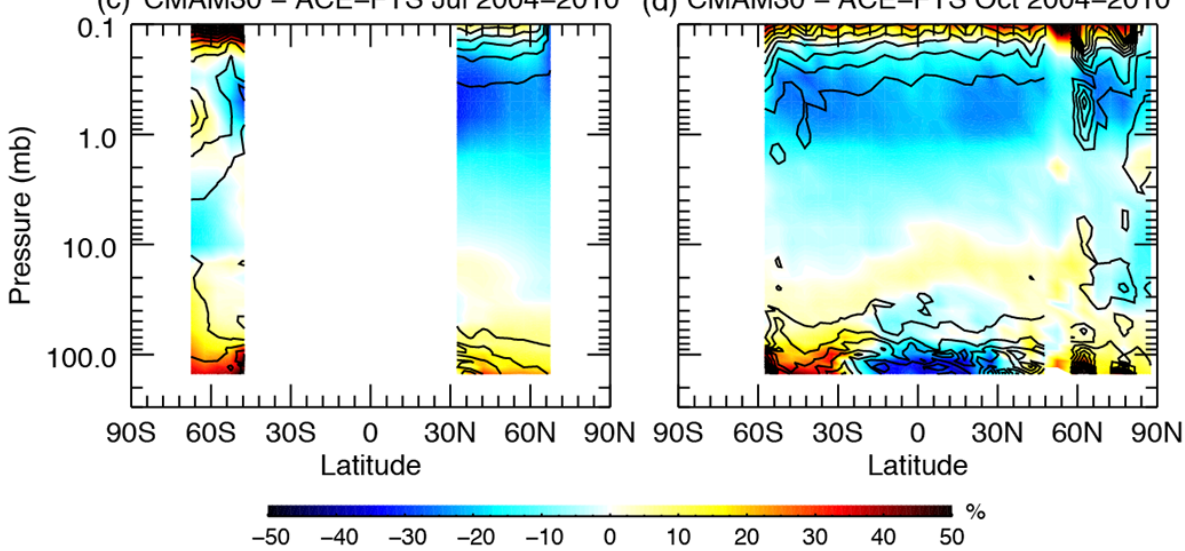

Figure 3. Same as for Fig. 1 but for CMAM30 vs. ACE-FTS absolute temperature differences for 2004 to 2010 for January (a), April (b), July, (c) and October (d). Note that the vertical axis here is pressure.

periment) and MIPAS (Michelson Interferometer for Passive Atmospheric Sounding) data sets (de Maziére et al., 2008) and descends over a period of a few months. While the model can simulate this feature, the CMAM30 methane does not decrease as rapidly as the ACE-FTS observations over the narrow vertical range. Because of the small values of methane at these altitudes, a discrepancy of only $0.1 \mathrm{ppmv}$ in methane can translate into a relative error of well over $100 \%$. The high MAD values around the regions of higher discrepancy are likely due to the variability and the descent of the kink. Above and below this region, however, CMAM30 does a good job of representing methane, aside from a background bias (i.e. the variability of the bias is low).

Figures 7 to 10 show the time series comparisons for the $\mathrm{NH}$ and $\mathrm{SH}$ polar regions (60 to $90^{\circ} \mathrm{N}$ and 60 to $90^{\circ} \mathrm{S}$, respectively). The time series plots show that the differences in the zonally averaged plots are repeated year after year. Most notable in the ozone profile differences for both OSIRIS and ACE-FTS is the overabundance of ozone in the model in the winter or spring in the SH lower stratosphere (Figs. 8a and $9 \mathrm{~b})$. In this region, the ozone amounts are low, and in the late winter or spring, as the Sun rises, the ozone hole develops, leading to even lower ozone concentrations. It is clear that the CMAM30 data set does not simulate enough ozone destruction during this period, also evidenced by the comparison of October total-column ozone over the South Pole in Shepherd et al. (2014). In addition, comparisons with the ACE-FTS profiles of water vapour show that in the same region and time period (Fig. 9c), there is an overabundance of water vapour in CMAM30 (up to 50\%), indicating that the dehydration of the polar vortex due to PSC formation is weak, which is unsurprising given the lack of PSC sedimentation. Results from the NH (Fig. 10c) do not show the same discrepancy in water vapour, perhaps to be expected since Arctic stratospheric temperatures are typically too warm to allow for Type 2 PSC particle formation and dehydration of the Arctic vortex and show only a notable high bias in ozone during three winters: 2004/2005, 2006/2007, and 2007/2008 (Figs. $8 \mathrm{~b}$ and 10b). The descent of the high bias in methane (see above) can clearly be seen in Figures 9d and 10d, primarily during the summer and fall for each hemisphere.

\subsection{Southern polar winter and/or spring}

The southern polar vortex is typically strong and chemically isolated (WMO, World Meteorological Organization). Results from Sect. 4.1 show that the polar vortex in the lower stratosphere in CMAM30 is too wet and there is too much ozone. There are two possible explanations for this be- 

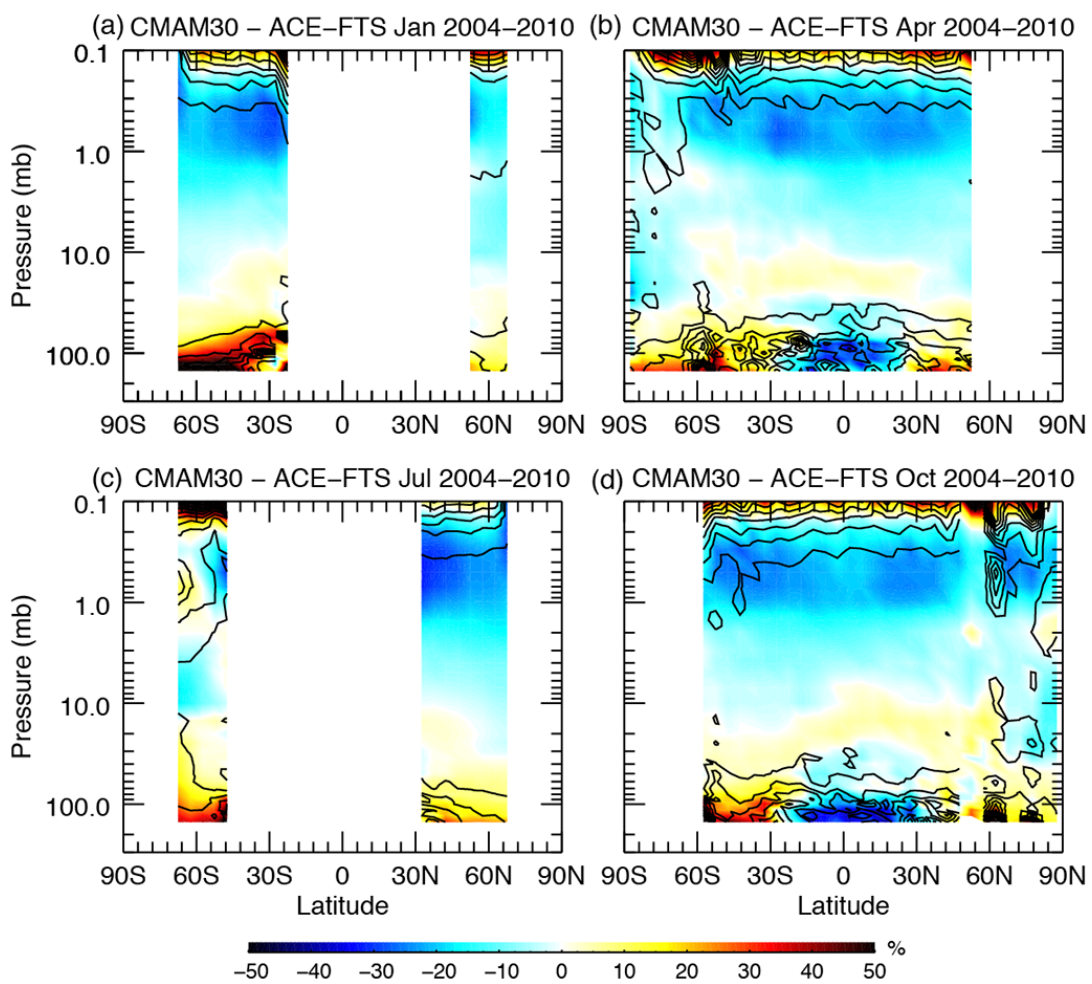

Figure 4. Same as for Fig. 2 but for CMAM30 vs. ACE-FTS relative differences for ozone profiles for 2004 to 2010.
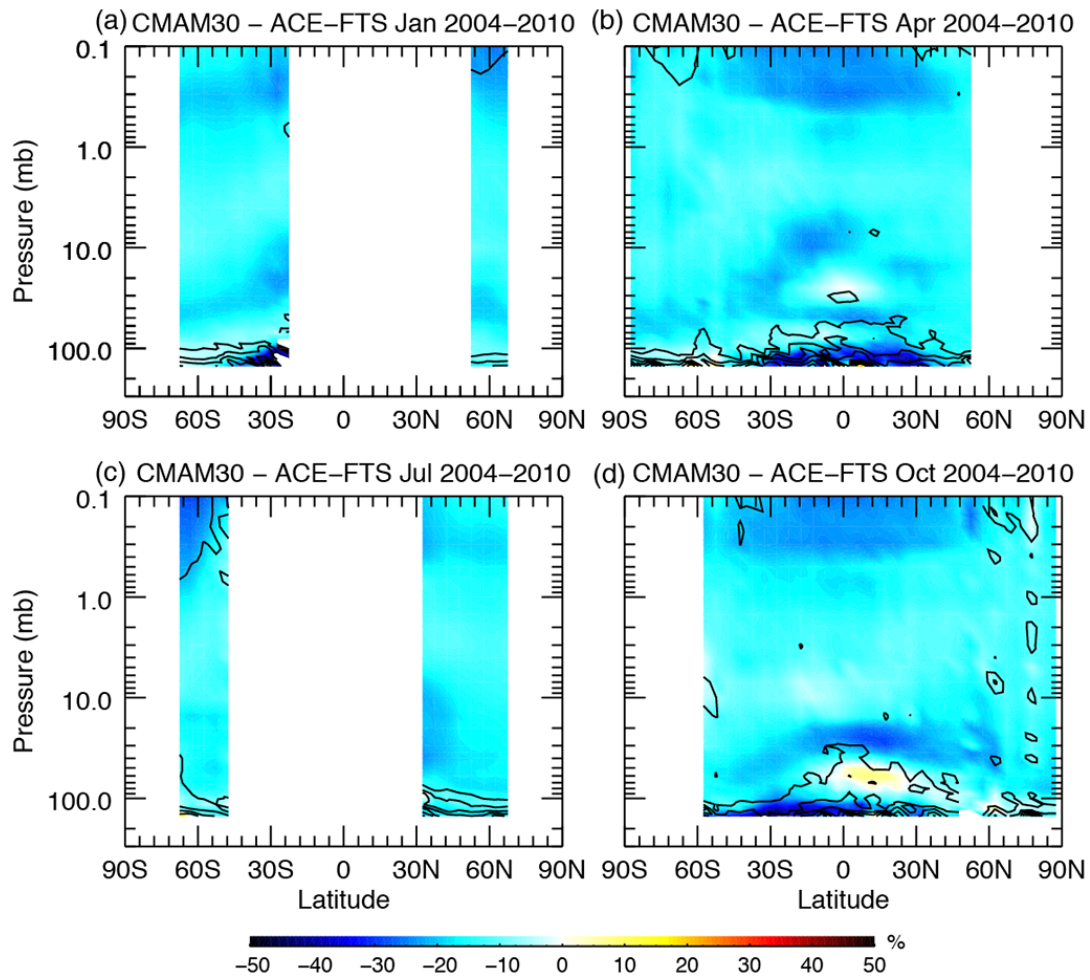

Figure 5. Same as for Fig. 2 but for CMAM30 vs. ACE-FTS relative differences for water vapour profiles for 2004 to 2010. 

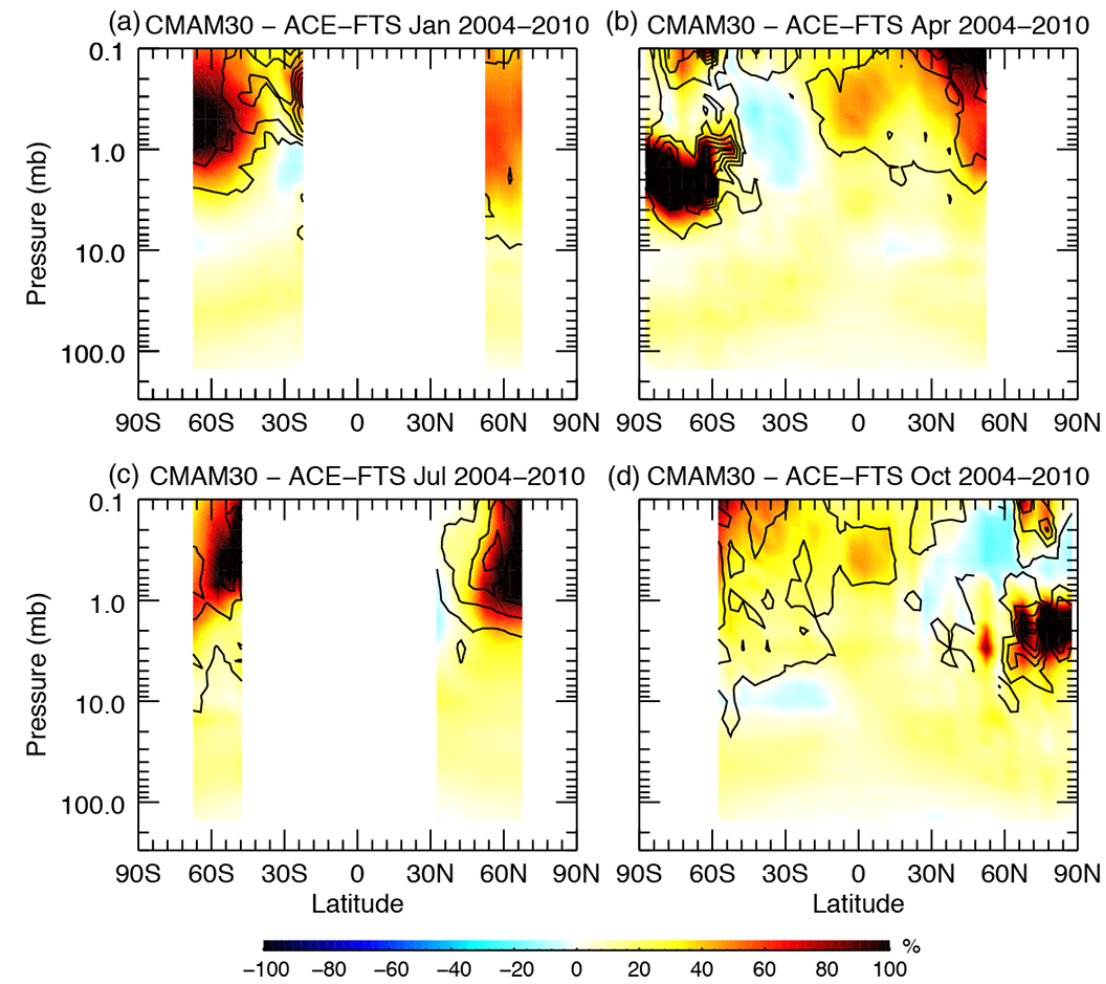

Figure 6. Same as for Fig. 2 but for CMAM30 vs. ACE-FTS relative differences for methane profiles for 2004 to 2010.

haviour: either chemical destruction of ozone during winter and spring is too low and dehydration of the polar vortex (e.g. due to PSC formation) is too low or the polar vortex is too isolated with too little horizontal mixing out of the lowerstratospheric vortex and too much diabatic descent within the vortex. The latter problem would allow an increase in ozone due to ozone-rich air descending from the mesosphere inside the polar vortex. It may also account for an increase in water vapour in the lower-stratospheric vortex, although this is harder to account for given the overall dry bias in the CMAM30 data. In addition, CMAM30 methane would further indicate that the polar vortex isolation is not the answer to this puzzle, since there is no corresponding increase in methane. The comparison of the methane vertical profiles from CMAM30 with ACE-FTS observations shows, in fact, some combination of too little descent within the vortex and too much mixing of midlatitude air into the vortex. The growth in CMAM30 biases in ozone relative to the growth in methane biases between 30 July and 25 September (see Figs. 11 and 12 below) suggests that an underestimation of ozone chemical destruction accounts for a significant part of the CMAM30 ozone biases at the end of September.

Individual profiles comparing CMAM30 to OSIRIS and ACE-FTS are shown in Figs. 11 and 12, for selected dates during the winter or spring of 2006, chosen as a typical year (i.e. the results for 2006 from Sect. 4.1 are similar for this year compared to other years). OSIRIS does not measure during polar night, so only measurements in late August and beyond are available. Also, because of the orbit of the ACE satellite, ACE-FTS measurements do not reach the pole until late winter and are outside or on the edge of the polar vortex during mid-winter. Near $50 \mathrm{hPa}$, a maximum high bias in water vapour is reached during August and early September when ACE-FTS measures near the pole and diminishes in October and November (Fig. 9c). The high bias in CMAM30 ozone persists throughout the late winter or spring (Fig. 9b).

Figures 11 and 12 also show the CMAM30 temperature, ozone, water vapour and methane on the $500 \mathrm{~K}$ isentropic surface from the CMAM30 data. Grey shaded regions indicate selected scaled potential vorticity (sPV) values associated with the polar vortex such that no shading (greater than $-1 \times 10^{-4} \mathrm{~s}^{-1}$ ) is outside the polar vortex and greys are inside the surf zone and inside the polar vortex $\left(>-1 \times 10^{-4} \mathrm{~s}^{-1}\right.$ is white, -1 to $-1.2 \times 10^{-4} \mathrm{~s}^{-1} \times 10^{-4} \mathrm{~s}^{-1}$ is light grey, -1.2 to $-1.4 \times 10^{-4} \mathrm{~s}^{-1}$ is medium grey, -1.6 to $-1.8 \times 10^{-4} \mathrm{~s}^{-1}$ is darker grey, and $<-1.8 \times 10^{-4} \mathrm{~s}^{-1}$ is darkest grey, which is considered to be deep inside the vortex). Temperatures that are less than 188 and $196 \mathrm{~K}$ are denoted by white contours for each isentropic map, and the locations of the tangent height of the satellite observations are also indicated (white crosses for ACE-FTS and white Xs for OSIRIS).

Throughout the winter, the polar vortex is stable and for the most part zonally symmetric except for a small wave 


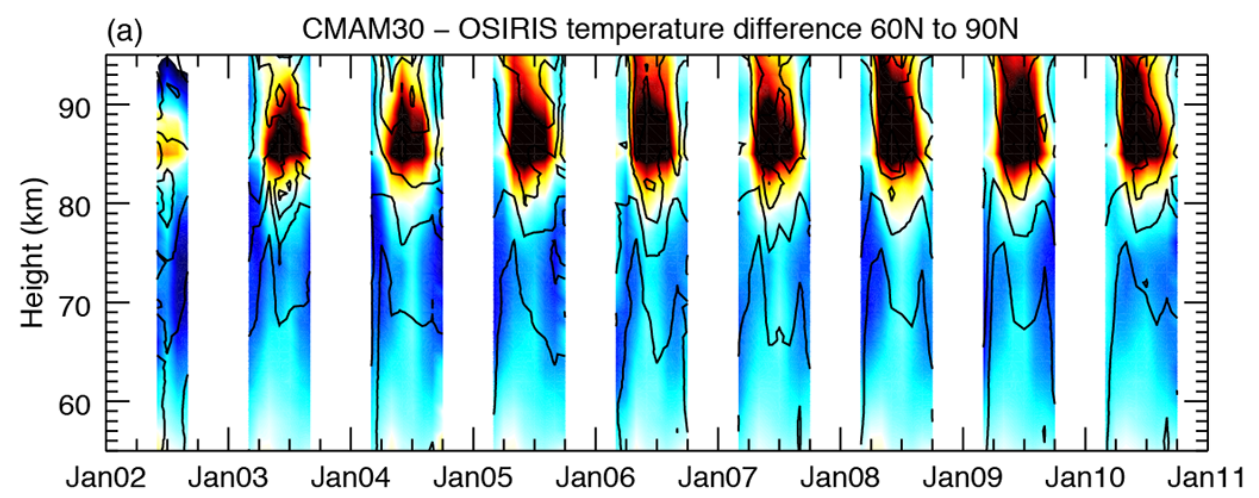

(b) CMAM30 - OSIRIS temperature difference $90 \mathrm{~S}$ to $60 \mathrm{~S}$

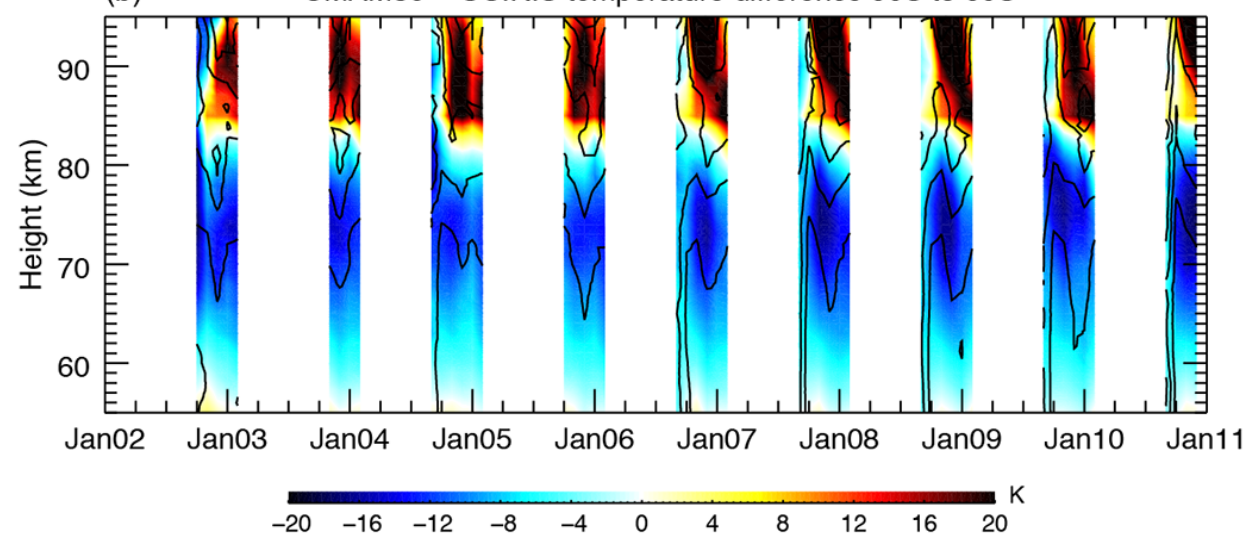

Figure 7. Time series comparison of coincident profiles between CMAM30 temperatures and OSIRIS temperatures derived from the $\mathrm{O}_{2}$ A-band for $90^{\circ} \mathrm{S}$ to $60^{\circ} \mathrm{S}$ (a) and $60^{\circ} \mathrm{N}$ to $90^{\circ} \mathrm{N}$ (b). Colours indicate the median bias of CMAM30 data. Contours indicate the MAD with contour intervals of $2 \mathrm{~K}$.

number 1 signature. The gradients of the chemical species follow the potential vorticity pattern closely throughout the winter. This pattern extends from $\sim 400 \mathrm{~K}$ up to $\sim 2500 \mathrm{~K}$, above which the diurnal cycle of ozone becomes important (not shown). As the season progresses and the wave 1 pattern becomes more pronounced, ACE-FTS can sample both inside and outside the vortex on 1 day (see Fig. 12). There is considerable agreement between the ACE-FTS and CMAM30 profiles in terms of the shape even though the CMAM30 water vapour (methane) profiles show a low (high) bias, except in the lowest part of the stratosphere.

As the season progresses, the discrepancy in the lowerstratosphere water vapour disappears (see Fig. 9c). The model sequesters water vapour, in the presence of sufficiently low temperatures, into PSCs, but they do not sediment out; rather they remain as PSCs until the temperature warms sufficiently for them to that they become water vapour again. By the end of September, only very small regions of the vortex are at temperatures cold enough to support water-ice PSCs, so the water has been returned to the gas phase. Separate plots of solid $\mathrm{H}_{2} \mathrm{O}$ (not shown) on the $500 \mathrm{~K}$ surface show an increase over the winter months and decrease during spring, in accordance with the area of temperatures below the 196 and $188 \mathrm{~K}$ thresholds.

Figure 13 shows daily polar vortex averages over the winter on the $500 \mathrm{~K}$ isentropic surface to diagnose the chemical destruction of ozone. Both ACE-FTS $\left(\mathrm{O}_{3}, \mathrm{H}_{2} \mathrm{O}, \mathrm{HNO}_{3}\right.$, $\mathrm{ClONO}_{2}$ and $\left.\mathrm{HCl}\right)$ and Aura-MLS data $\left(\mathrm{O}_{3}, \mathrm{H}_{2} \mathrm{O}, \mathrm{HNO}_{3}\right.$, $\mathrm{ClO}$ and $\mathrm{HCl}$ ) are compared to CMAM30 data. For both satellites, the SPV values from the derived meteorological products from GEOS5 (ACE-FTS) and MERRA (AuraMLS) are used to determine if profile measurements are inside or outside the polar vortex. The polar vortex is defined as $\mathrm{sPV}<-1.2 \times 10^{-4} \mathrm{~s}^{-1}$ for the SH and $\mathrm{SPV}>1.2 \times 10^{-4} \mathrm{~s}^{-1}$ for the $\mathrm{NH}$, although the results are similar for values of $\mathrm{SPV}$ between -1.2 and $-2 \times 10^{-4} \mathrm{~s}^{-1}$ (and 1.2 and $2 \times 10^{-4} \mathrm{~s}^{-1}$ for the $\mathrm{NH})$. For the $\mathrm{SH}, 2006$ was chosen as a typical year, and for the NH, 2005 was chosen since it was a year with no SSWs during the winter, producing a cold and persistent polar vortex (see below). Note in Fig. 10 that the ozone discrepancies are greatest in the 2004/2005 NH winter-spring season. Errors in Fig. 13 are calculated as follows. For ACEFTS data, cumulative errors based on the reported errors, which are a statistical deviation calculated from the retrieval process, are shown. For Aura-MLS data, the reported errors, 

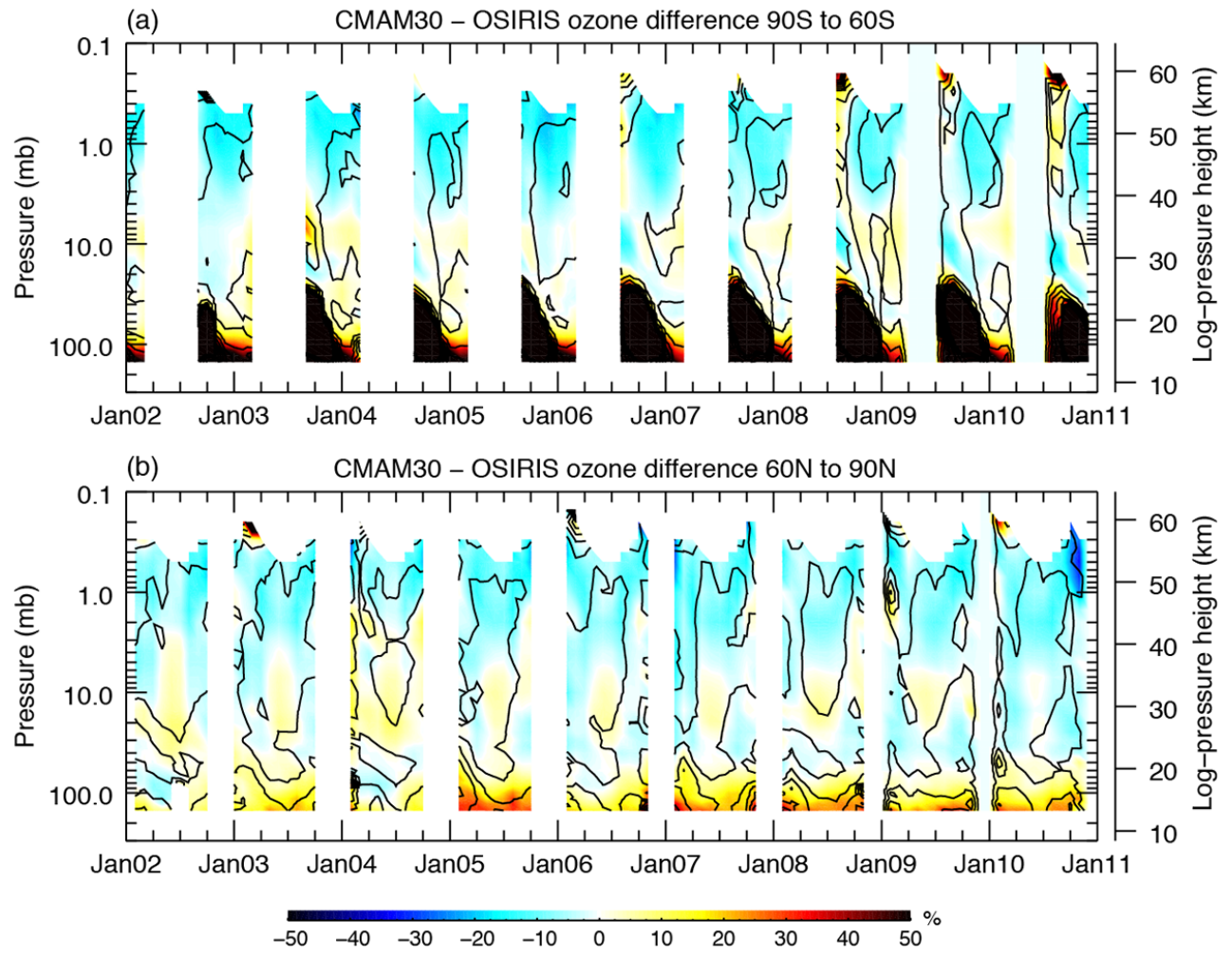

Figure 8. Same as for Fig. 7 but for time series of relative differences between CMAM30 and OSIRIS ozone. Colours indicate the median bias, and contours indicate the MAD with a contour interval of $5 \%$.

which indicate the precision of the instrument are used for two error calculations: the square root of the sum of the squared errors, which can be interpreted as the precision of the averaged measurements, and cumulative errors as calculated for ACE-FTS. The root mean square errors for AuraMLS are shown by the darker error bars, and the cumulative errors are indicated by the corresponding lighter shade for each species. The cumulative errors are calculated assuming that each measurement is consistently high or low to provide a maximal window within which the CMAM30 data should fall. The smaller window for the ACE-FTS measurements represents a smaller window of opportunity to evaluate the CMAM30 data due to the smaller number of measurements and does not imply greater accuracy of the instrument compared to Aura-MLS.

The top panels of Fig. 13 show the area of the polar vortex (as measured by the satellite instruments) on the $500 \mathrm{~K}$ isentropic surface (blue), the area of the polar vortex where $T<196 \mathrm{~K}$ (green), and the area of the polar vortex where $T<188 \mathrm{~K}$ (pink) for the SH winter (2006) and the NH winter (2005). For the purpose of assigning area to each satellite profile, a footprint of $500 \mathrm{~km}$ is assumed for ACE-FTS and a footprint of $220 \mathrm{~km}$ is assumed for Aura-MLS. Note that this is necessary since neither satellite measures the entire polar vortex but rather subsamples the vortex. Any area-based averaging must take this subsampling into account. The foot- print areas are based on technical documents available from the Aura-MLS website (Livesey et al., 2013) and the ACEFTS website.

The middle panels of Fig. 13 show the evolution of water vapour (solid and gas phase) and $\mathrm{HNO}_{3}$ (solid and gas phase) over the winter or spring in both hemispheres. Solid phase is shown only for CMAM30 data since the satellites do not retrieve solid $\mathrm{HNO}_{3}$ or water vapour. At the beginning of the winter (1 July), CMAM30 water vapour (purple solid line) is low compared to Aura-MLS (purple crosses) and ACE-FTS (purple triangles). However, as the season progresses, CMAM30 water vapour amounts agree well with Aura-MLS, likely indicating that not enough water vapour in the CMAM30 is sequestered as solid. Note that although the $\mathrm{H}_{2} \mathrm{O}$ amounts appear to agree, CMAM30 should have a ubiquitous low bias to be consistent with earlier results. Although the $\mathrm{H}_{2} \mathrm{O}$ agrees in this region, it is because there is not enough water vapour at the beginning of the season, and not enough is sequestered as PSC aerosol. CMAM30 is also higher than ACE-FTS. Note that ACE-FTS measures near $60^{\circ} \mathrm{S}$ at the beginning of the winter, and by August the orbit progresses such that the measurements are closer to the pole (or vortex core) where temperatures are colder. This sampling pattern of the polar vortex is likely the reason that ACEFTS has very high values of $\mathrm{HNO}_{3}$ (blue triangles) at the beginning of the winter compared to Aura-MLS (blue crosses) 

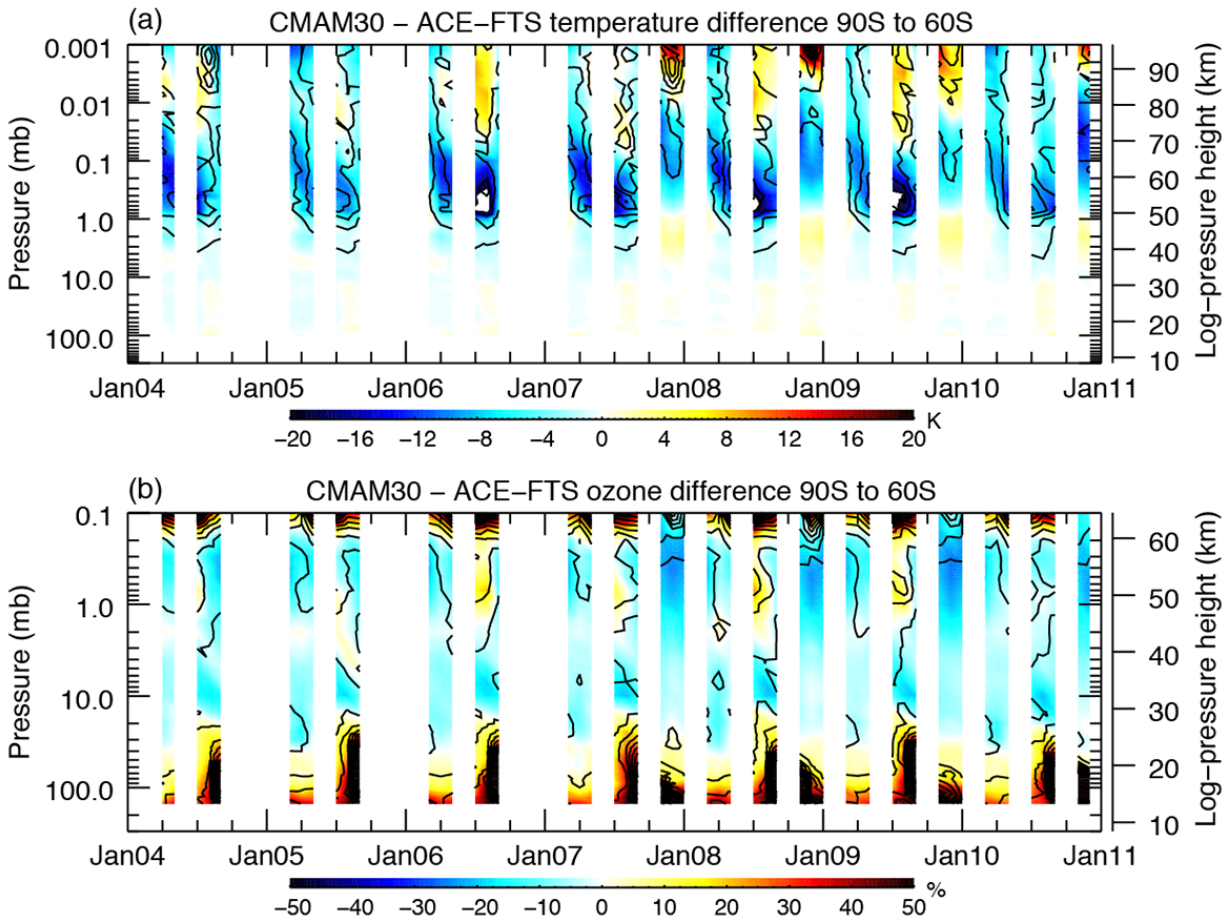

(c) CMAM30 - ACE-FTS water vapour difference 905 to $60 S$
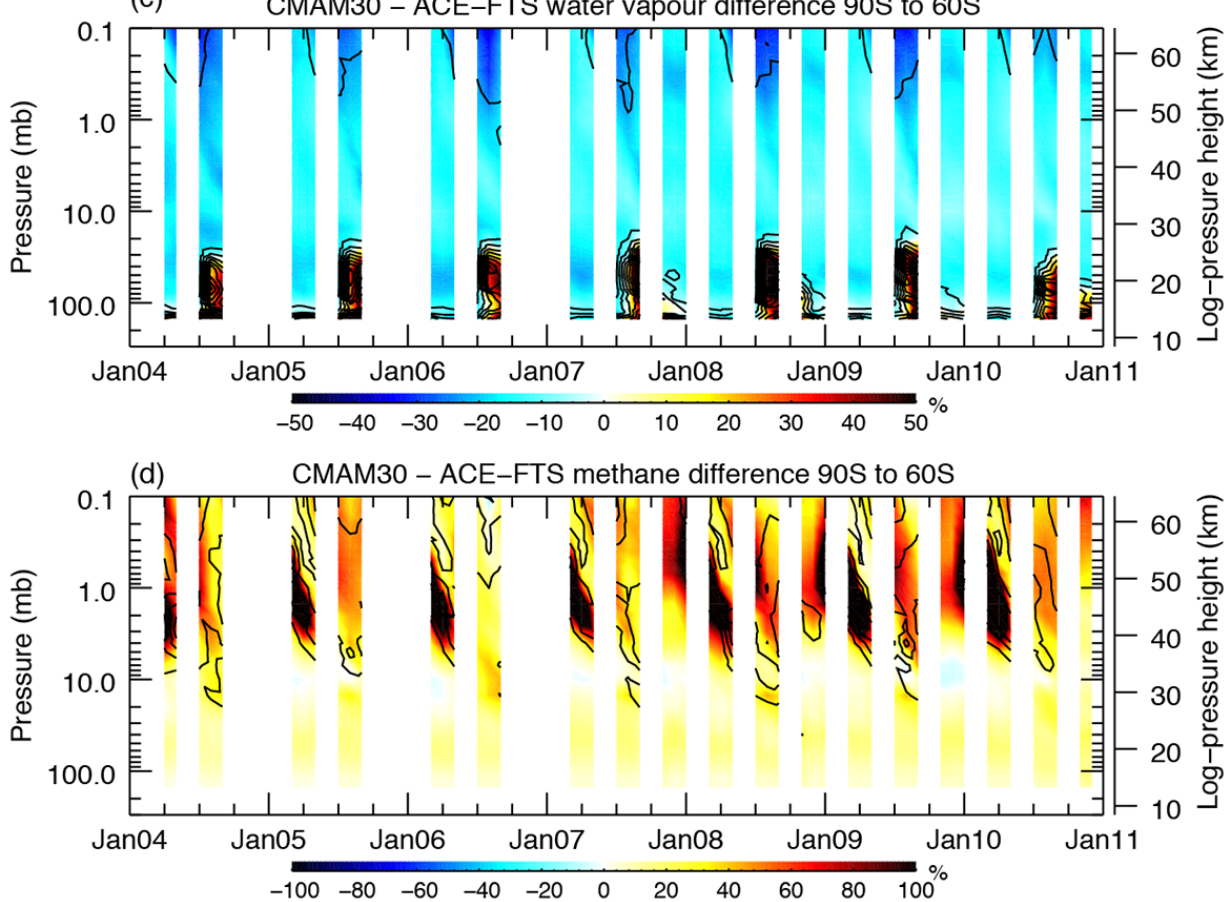

Figure 9. Time series of absolute differences for temperature (a) of coincident profiles between CMAM 30 and ACE-FTS for 90 to $60^{\circ} \mathrm{S}$ and for relative differences for ozone (b), water vapour (c) and methane (d). Colours indicate the median bias of CMAM30 data. Contours indicate the MAD with a contour interval of $2 \mathrm{~K}$ for temperature and $5 \%$ for tracers.

and measures almost no gas phase $\mathrm{HNO}_{3}$ by the end of $\mathrm{Au}-$ gust and the beginning of September. The fact that ACE-FTS samples only certain latitudes on certain dates must be taken into account when comparing the data. The effect of the ACE orbit on the vortex averaging results is discussed in Santee et al. (2008b). CMAM30 has gas phase $\mathrm{HNO}_{3}$ (blue solid line) that is too high compared to Aura-MLS for the entire season in the SH. The formation of PSC aerosol (pink) and 

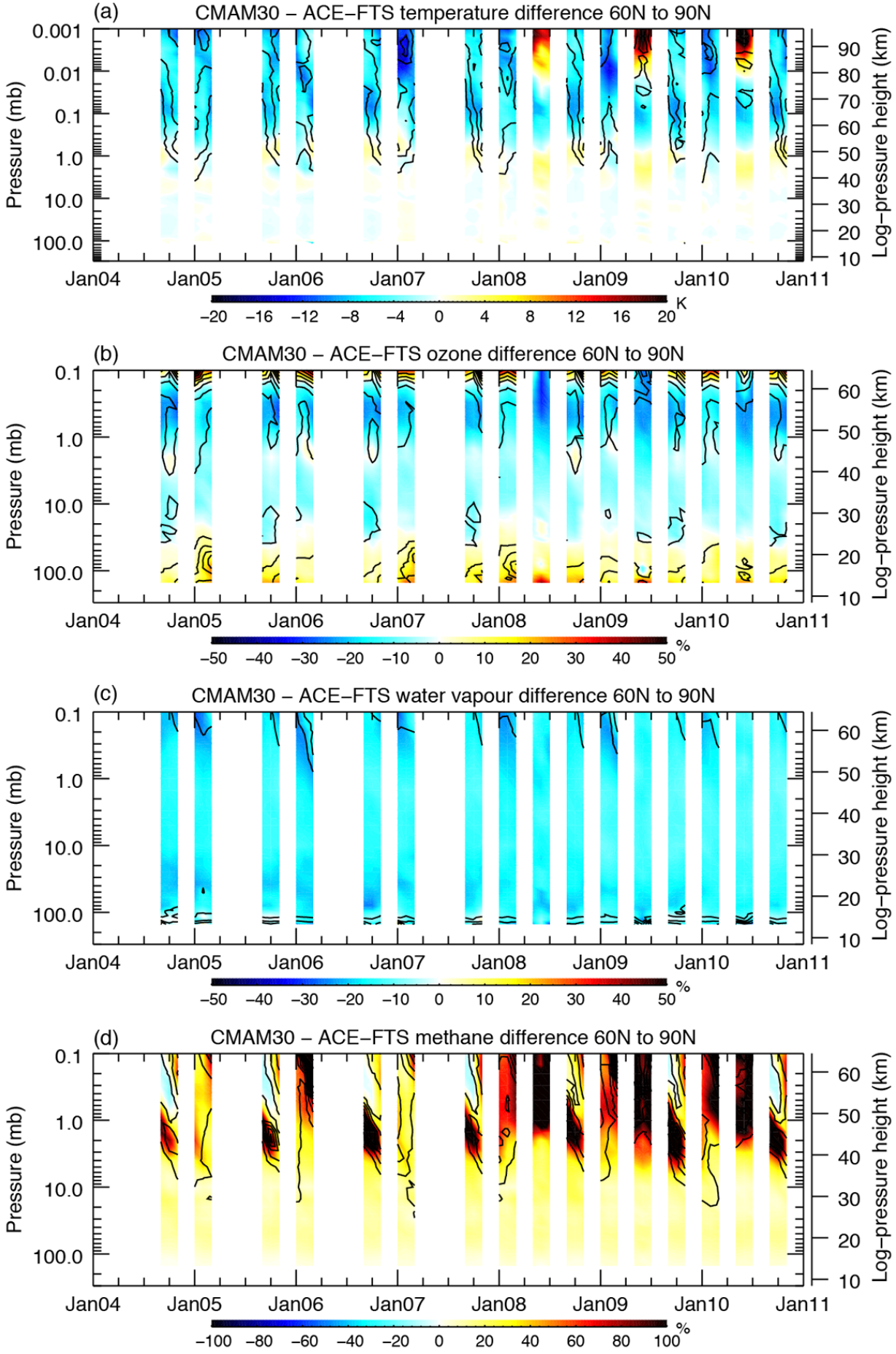

Figure 10. Same as for Fig. 9 but for 60 to $90^{\circ} \mathrm{N}$.

solid-phase $\mathrm{HNO}_{3}$ (green) in the CMAM30 data agrees well with the timing of the temperature thresholds seen in the top panels of Fig. 13.

The bottom panels in Fig. 13 show the concentrations of ozone, the chlorine reservoirs $\mathrm{HCl}$ and $\mathrm{ClONO}_{2}$, and active chlorine $\mathrm{ClO}\left(\mathrm{HOCl}\right.$ and $\mathrm{Cl}_{2}$ were also examined but are not shown since the results are similar). At the beginning of the SH winter, CMAM30 ozone (purple solid line) agrees well with that from both Aura-MLS (purple crosses) and ACE-FTS (purple triangles), but while the satellite observations quickly show a drop in ozone concentration that persists as the winter and spring progress, CMAM30 does 

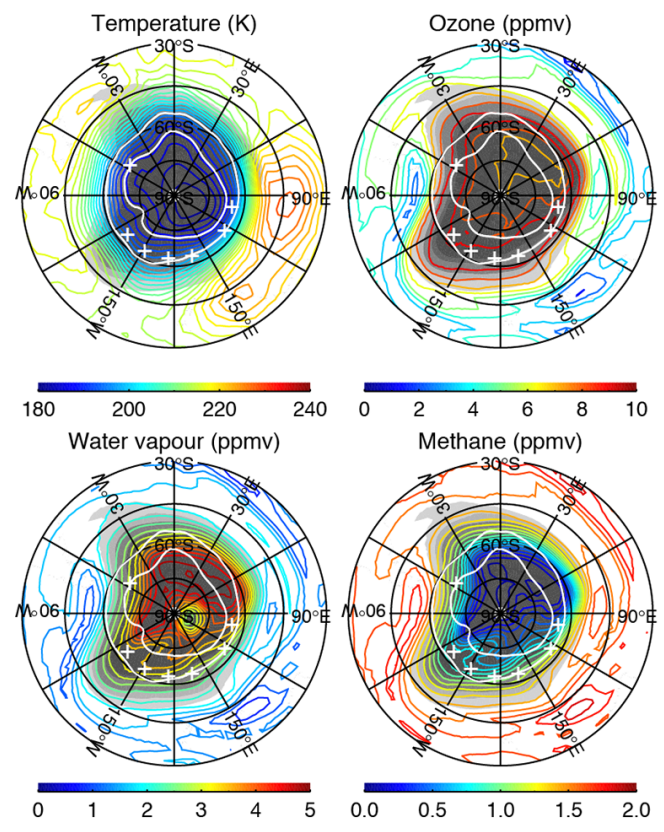

CMAM30 - ACE-FTS
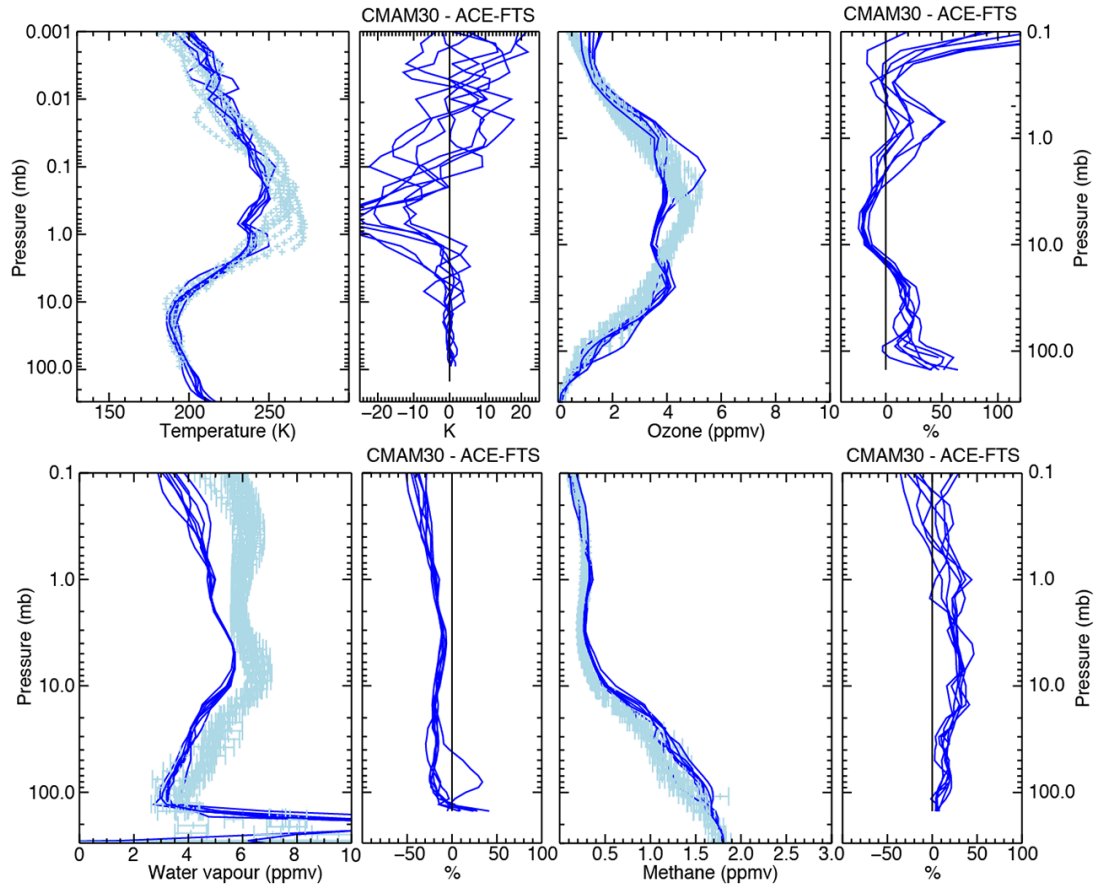
СМАМЗ - ACE-FTS
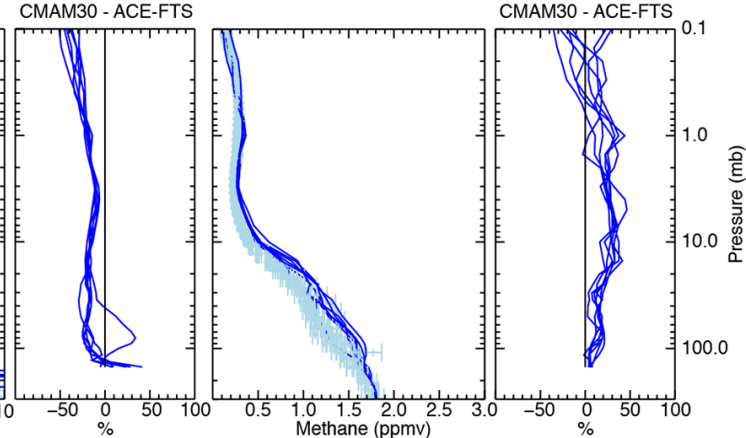

Figure 11. Left panels show the CMAM30 temperature, ozone, water vapour and methane on the $500 \mathrm{~K}$ isentropic surface for $30 \mathrm{July} 2006$. Coloured contours are the constituent and/or temperature values. Scaled potential vorticity is shaded in grey (no shading less than $-1 \times$ $10^{-4} \mathrm{~s}^{-1}$; light shading at -1 and $-1.2 \times 10^{-4} \mathrm{~s}^{-1}$; darker shading -1.6 and $-1.8 \times 10^{-4} \mathrm{~s}^{-1}$ ). The white contours indicate where the temperature is below 196 and $188 \mathrm{~K}$. Right panels show coincident profiles for CMAM30 (dark blue) and ACE-FTS measurements (light blue) for temperature, ozone, water vapour and methane. Differences between CMAM30 and ACE-FTS are shown to the right of each panel. Locations of each profile are marked on the isentropic plots for ACE-FTS profiles (white crosses). Note there are no OSIRIS data available for this date.

not. The lack of substantial change in CMAM30 ozone during July and August can be explained by the lack of the active chlorine $\mathrm{ClO}$ (green), which is produced by heterogeneous chemistry on PSCs surfaces. CMAM30 produces only half of the $\mathrm{ClO}$ concentration compared to Aura-MLS. Correspondingly, CMAM30 also shows too much $\mathrm{HCl}$ (blue) for the winter before September compared to both Aura-MLS and ACEFTS, although a "bite" out of the $\mathrm{HCl}$ can be seen as $\mathrm{HCl}$ is converted to more reactive chlorine species on PSC surfaces. Note the rapid decline in $\mathrm{HCl}$ around 31 July when $\mathrm{ClONO}_{2}$ and $\mathrm{ClO}$ begin to increase and the rapid increase in $\mathrm{HCl}$ during the first week of October. $\mathrm{ClONO}_{2}$ in the CMAM30 data is also high compared to ACE-FTS from mid-August to late September. During this time period, ACE-FTS measures almost no $\mathrm{ClONO}_{2}$, while CMAM30 shows a persistent increase in concentration, indicating that the chlorine reservoir recovers too quickly. By the end of September, ACE-FTS and CMAM30 amounts agree well, however, since the orbit of ACE takes the measurement latitudes rapidly through the "collar region" of the vortex (mid- to high latitudes) during this part of the year (see Santee et al., 2008b), the agreement may be coincidental. Note during this period, ozone as observed by ACE-FTS also increases rapidly, unlike the AuraMLS and CMAM30 ozone.

\subsection{Northern polar winter and/or spring}

Northern Hemisphere winters experience SSWs in some years, some of which are dynamically very strong and greatly disturb the vortex. In such cases, large wave number 1 and 2 disturbances are seen before the SSW. After the SSW, depending on the winter, the vortex can be very warm and weak, with an almost isothermal stratosphere. During winters with no SSW, the polar vortex is less dynamically active, more isolated and colder, although it rarely becomes as cold as the southern polar vortex (see Andrews et al., 1987).

Figure 13 (right column) shows the evolution of the polar vortex for $\mathrm{NH}$ winter or spring for a winter with no SSWs (2005). This is the only winter during the ACE-FTS and Aura-MLS satellite observational periods overlapping with the CMAM30 data set that does not have an SSW during winter. The polar vortex area (blue) is slightly reduced compared to the SH winter, but the regions of $T<188 \mathrm{~K}$ (pink) and $T<196 \mathrm{~K}$ (green) are greatly reduced (top right panel). The model shows a small amount of solid-phase $\mathrm{HNO}_{3}$ (green), and a corresponding dip in the gas phase $\mathrm{HNO}_{3}$ (blue), at the end of January (middle right panel of Fig. 13), but the amount of solid water vapour in the model in the vortexaveraged view is several orders of magnitude too small to be 

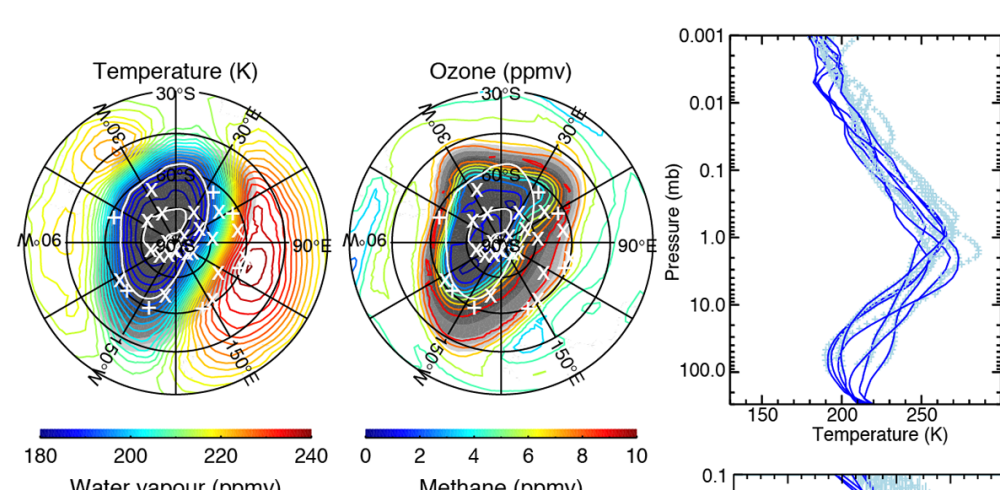

CMAM30 - ACE-FTS
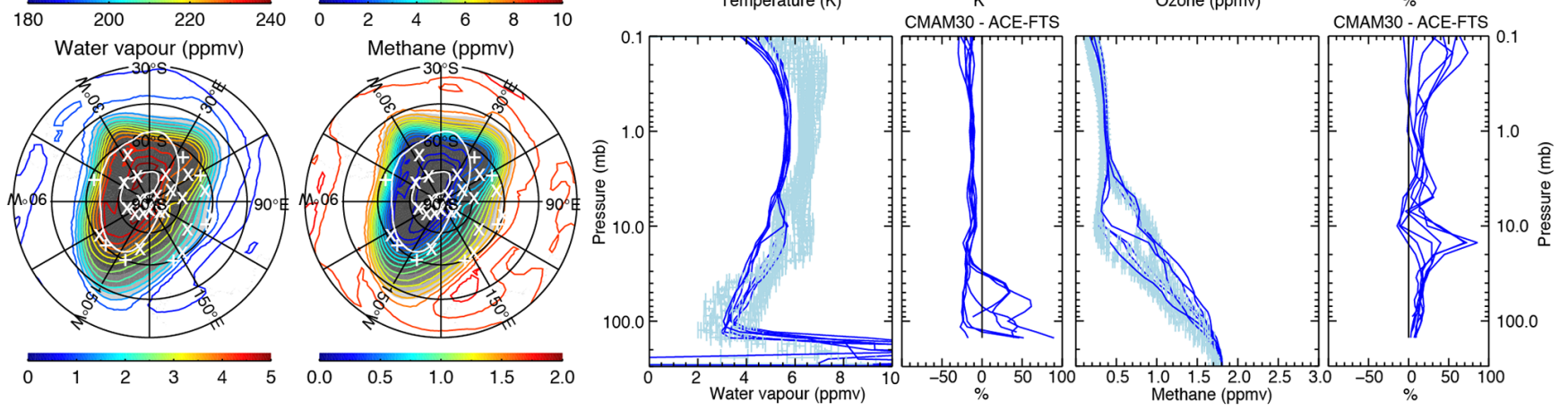

Figure 12. Same as Fig. 11 but for 25 September 2006. OSIRIS measurements are grey, with CMAM30 coincident profiles in red and differences with respect to OSIRIS in red. Locations of each profile are marked on the isentropic plots for ACE-FTS profiles (white crosses) and for OSIRIS (white Xs).

noted. Note that there is no difference in the model results if the $450 \mathrm{~K}$ isentropic surface is used for the vortex-averaged view. The gas phase $\mathrm{HNO}_{3}$ for the $\mathrm{NH}$ polar vortex agrees reasonably well over the whole winter season, although it is slightly high compared to Aura-MLS measurements during January and February, except during the aforementioned increase in solid-phase $\mathrm{HNO}_{3}$. However, gas phase $\mathrm{HNO}_{3}$ in the model is low in the spring compared to both Aura-MLS and ACE-FTS. Gas phase water vapour in the CMAM30 is low by $\sim 20 \%$ over the entire time period, consistent with the results shown in Fig. 5.

The right bottom panel of Fig. 13 shows that throughout most of the late winter or early spring, CMAM30 has too much ozone (purple) compared to ACE-FTS and Aura-MLS, but the bias is greatly reduced compared to the SH winter or spring. The seasonal variation in $\mathrm{HCl}$ (blue) from Aura-MLS and ACE-FTS agrees well over the season, but both data sets disagree with CMAM30, which shows no variation in $\mathrm{HCl}$ over the season. As in the $\mathrm{SH}$, however, CMAM30 shows much less $\mathrm{ClO}$ (green) than Aura-MLS, and this discrepancy can account for the lack of seasonal variation in $\mathrm{HCl}$ in the model. CMAM30 $\mathrm{ClONO}_{2}$ (pink) compares reasonably well with ACE-FTS in January, but while the ACE-FTS data set shows no evidence of $\mathrm{ClONO}_{2}$ in March and April, the CMAM30 data set consistently shows approximately 1 ppbv. However, overall, despite the disagreement between the active chlorine and the chlorine reservoir $\mathrm{HCl}$, by April, ozone in the CMAM30 agrees well with the satellite data, indicat- ing that the treatment of PSCs in the model in the $\mathrm{NH}$ may not be as critical as in the $\mathrm{SH}$, even during cold Arctic winters. These results are supported by the monthly zonal mean differences of ozone (Figs. 2, 4, 8, 10), showing that the high bias in ozone during January and February over high northern latitudes is not as high or as long-lasting as during the $\mathrm{SH}$ winter or spring season over high southern latitudes.

Since the CMAM30 nudges spatial scales up to wave number 21 , it should be expected to faithfully reproduce SSWs and the large-scale dynamical variability of the stratosphere. Agreement should be expected to decrease somewhat in the mesosphere, where there is no nudging and smaller spatial scales dominate. Unsurprisingly, an examination of the dynamical fields during SSW events (start date and type split vs. displacement) in the CMAM30 data set shows exact agreement with the ERA-Interim data set; however, the chemical tracers may deviate from observations.

Figure 14 shows coincident profile comparisons for 25 January 2006, just after an SSW that occurred on 21 January 2006. On this date, the polar vortex is highly distorted, but the coldest temperatures are still in the vicinity of the vortex, and isolines for all three tracers track the vortex edge very well. Note that the coldest temperatures outlined by the white contours are just outside the vortex edge. Temperature and ozone profiles agree remarkably well both inside and outside the vortex, although CMAM30 does not quite capture the ozone maximum $(\sim 8 \mathrm{ppmv}$ at $\sim 1 \mathrm{hPa})$. The profiles also agree well for both water vapour and methane, despite 

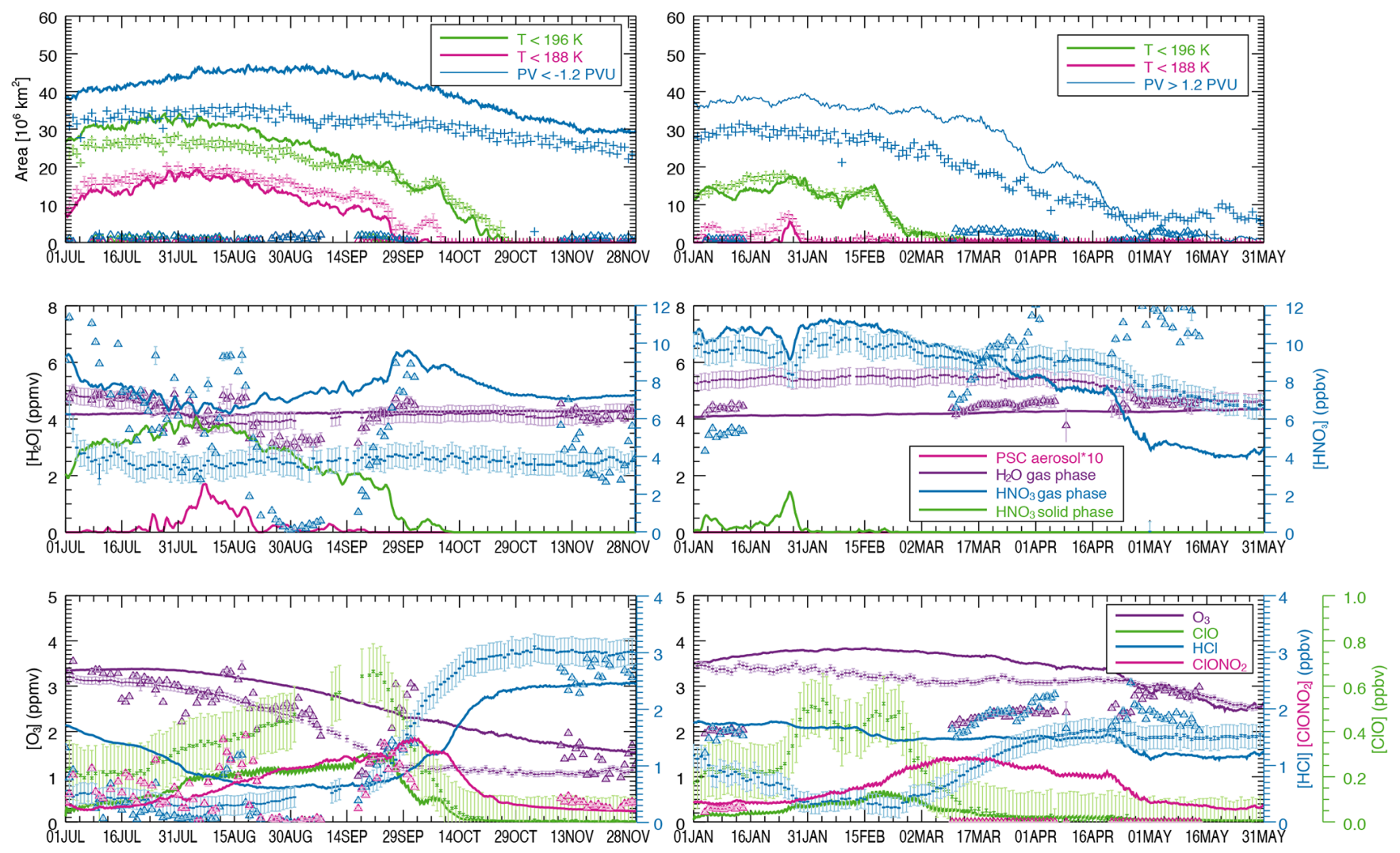

Figure 13. Polar vortex diagnostics for SH winter 2006 (left column) and NH winter 2005 (right column) on the $500 \mathrm{~K}$ isentropic surface. Top panels show the area of polar vortex defined as $\mathrm{SPV}>1.2 \times 10^{-4} \mathrm{~s}^{-1}$ (blue) for the NH and sPV $<-1.2 \times 10^{-4} \mathrm{~s}^{-1}$ for the SH, area where temperature is below $196 \mathrm{~K}$ (green) and below $188 \mathrm{~K}$ (pink). The middle panels show polar vortex averaged $\mathrm{H}_{2} \mathrm{O}$ (purple), $\mathrm{HNO}_{3}$ (blue), solid $\mathrm{H}_{2} \mathrm{O}$ or PSC aerosol (pink) and solid $\mathrm{HNO}_{3}$ (green). Bottom panels show polar-vortex-averaged ozone (purple), $\mathrm{HCl}$ (blue), $\mathrm{ClO}$ (green, Aura-MLS and CMAM30 only) and $\mathrm{ClONO}_{2}$ (pink, ACE-FTS and CMAM30 only). CMAM30 is shown as solid lines, ACEFTS as triangles with error bars (cumulative errors), and Aura-MLS as dots with error bars (root mean square errors in dark colours and cumulative errors in corresponding lighter colours). Solid water vapour (PSC aerosol, CMAM30 only) amounts are scaled by a factor of 10. Note that $\mathrm{HNO}_{3}$ and $\mathrm{ClO}$ amounts for the middle and bottom panels, respectively, are denoted on the rightmost axes for both left and right columns.

the consistent low bias in CMAM30 water vapour of $20 \%$ and a high bias of $10-40 \%$ in methane. The increase with height in the relative differences for methane is a result of the decrease in concentration.

\section{Discussion and conclusions}

The Canadian Middle Atmosphere Model, a chemistryclimate model, has been nudged by ERA-Interim winds and temperatures to produce a data set that should reproduce the atmospheric state for the time period between 1979 and 2010. Here, the CMAM30 data set has been shown to have a good representation of the stratosphere for temperature, ozone, water vapour and methane for the 2004-2010 period, with a few exceptions.

The water vapour has an overall low bias in the CMAM30 relative to ACE-FTS (between 10 and 20\%). This bias is widespread and shows little variability. Additionally, methane shows an overall high bias of $\sim 20 \%$ in the stratosphere, again with little variability over the region. These discrepancies (high methane, low water vapour) may be explained by a Brewer-Dobson circulation in the model that is too fast, which could produce an over-dehydration of air entering the stratosphere through the tropical tropopause and would not allow enough time for methane to be converted into water vapour as air parcels circulate. The injection of air parcels into the stratosphere and the Brewer-Dobson circulation will be explored in an accompanying paper that examines the agreement of the CMAM30 data set in the tropical regions, the tropical upwelling in the model, and the residual circulation.

Methane shows more disagreement in the mesosphere (up to $100 \%)$. However, in this region, methane concentrations are extremely low and even small absolute differences produce large relative differences. Also, above $\sim 40 \mathrm{~km}$ ACEFTS shows more disagreement with other satellite instru- 

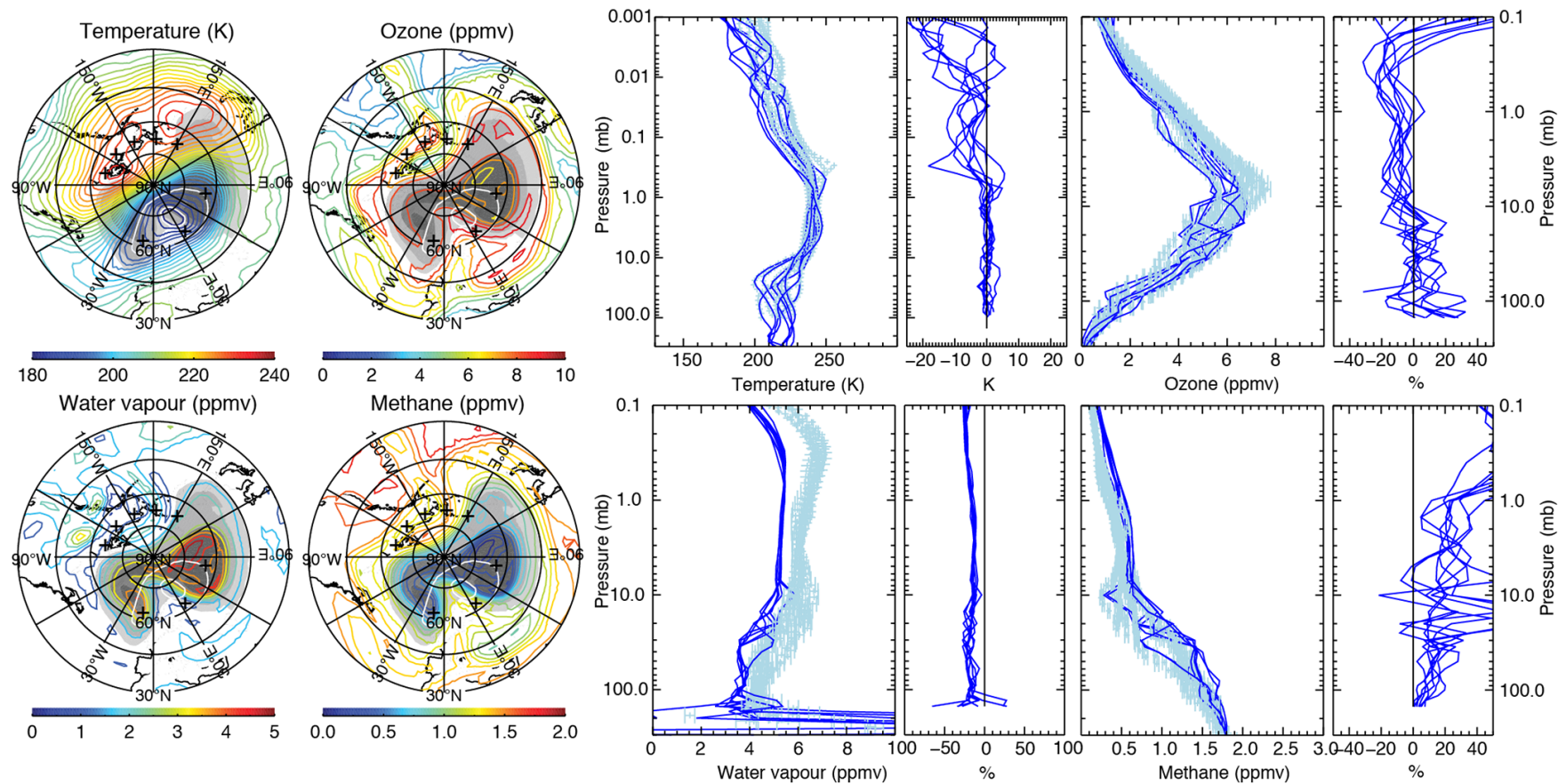

Figure 14. Same as for Fig. 11 but for 25 January 2006 in the NH. sPV values are $1,1.2,1.4,2,3.25 \times 10^{-4} \mathrm{~s}^{-1}$. The locations of the ACE-FTS profiles are marked on the maps by black crosses. No OSIRIS data are available for this date.

ments (de Maziére et al., 2008). There is also more variability at these altitudes, which is likely due to the abrupt change in the methane profile, which descends over a season (see Figs. 9d and 10d).

The SH polar winter or spring is less dynamically active than many other regions of the stratosphere. The CMAM30 data set shows a high bias in water vapour in the lower stratosphere, indicating a lack of polar vortex dehydration, and high ozone. Further analysis and comparisons with AuraMLS show that these discrepancies are due to the treatment of polar stratospheric clouds (PSCs) in the model. While the model sequesters solid $\mathrm{HNO}_{3}$ and $\mathrm{H}_{2} \mathrm{O}$ in the aerosol phase when the thermodynamic and chemical conditions are appropriate (typically when temperatures reach 196 and $188 \mathrm{~K}$, respectively), there is no sedimentation of PSC particles regardless of how long they persist. Thus the model does not allow for dehydration or denitrification of the springtime lower stratosphere. In addition, the model does not seem to sequester enough water vapour in PSCs in the winter lower-stratospheric vortex because CMAM30 water vapour in this region can be $\sim 20-30 \%$ too high despite the pervasive $\sim 10-20 \%$ low bias in this field.

It should be noted that the version of the CMAM used to produce the CMAM30 data set treats the advection of inorganic chlorine species by combining them into one of two advected tracers: $\mathrm{HCl}$ and $\mathrm{ClO}_{x}$. While $\mathrm{HCl}$ is treated explicitly, the advected $\mathrm{ClO}_{x}$ family must be partitioned into the individual chemical species before chemistry is calculated, which is accomplished by using the relative concentrations at each model grid point from the previous time step. This treatment effectively locks the $\mathrm{ClONO}_{2}$ concentration to the model grid and does not allow for regeneration of $\mathrm{ClONO}_{2}$ as air masses are advected from dark to sunlit portions of the polar vortex (Jaeglé et al., 1997). During polar night, the dominant reaction for chlorine activation is through the reaction of $\mathrm{HCl}$ with $\mathrm{ClONO}_{2}$, producing $\mathrm{Cl}_{2}$ and $\mathrm{HNO}_{3}$. In CMAM, as the winter progresses this pathway to chlorine activation shuts down once the $\mathrm{ClONO}_{2}$ is depleted (where there is complete darkness), since $\mathrm{ClONO}_{2}$ is typically less abundant than $\mathrm{HCl}$, leaving too much $\mathrm{HCl}$ and too little reactive chlorine. The comparisons presented here have partially motivated further model development. For instance, in a later version of the CMAM, $\mathrm{ClONO}_{2}$ is advected as a separate species, allowing for regeneration of $\mathrm{ClONO}_{2}$ within the sunlit portions of the polar vortex and allowing more conversion of $\mathrm{HCl}$ to reactive chlorine. These results are similar to those of Wohltmann et al. (2013), who found a consistent overestimation of $\mathrm{HCl}$ in the presence of PSCs regardless of which PSC processes were used, although their work focused on an $\mathrm{NH}$ winter with a major SSW. Similar results, again for the Arctic winter, were also found in Brakebusch et al. (2013), in which the Whole Atmosphere Community Climate Model was nudged to a meteorological analysis. The $\mathrm{ClONO}_{2}$ was found to be underestimated in early winter, leading to a high bias in ozone. However, the situation in Brakebusch et al. (2013) changes in late winter with an overestimate of $\mathrm{HNO}_{3}$ leading to high $\mathrm{ClONO}_{2}$. 
In the $\mathrm{NH}$ polar winter or spring, which is warmer and more dynamically active, the CMAM30 profiles agree well with both ACE-FTS and OSIRIS profiles, except for the uniform low bias of 10-20\% in water vapour and the high bias of methane. The large-scale dynamical variability is well captured by the CMAM30 data set. In addition, the treatment of PSCs in the model is not as important for the $\mathrm{NH}$ winter or spring as for the SH. Even during a cold year without an SSW, water vapour shows very little change from the consistent low bias and ozone shows only a temporary high bias. Note, however, that Jimenez et al. (2006) show that during the 2004/05 NH winter season there is only a single occurrence of short-lived dehydration in the winter vortex, indicating that the conditions during this winter may not reflect a typical year without an SSW. Overall, CMAM30 has a good, self-consistent representation of the stratosphere for ozone, temperature, water vapour and methane, when the overall biases in water vapour and methane are taken into account. However, treatment of PSCs in the SH polar vortex is not sufficient to accurately simulate the dehydration and ozone destruction during the $\mathrm{SH}$ late winter or spring.

Acknowledgements. Thanks to C. McLandress with help on the manuscript. This work and the development of the CMAM30 data set were funded by the Canadian Space Agency (CSA). Odin is a Swedish-led satellite project funded jointly by Sweden (Swedish National Space Board), Canada (CSA), France (Centre National d'Etudes Spatiales), and Finland (Tekes), with support by the third-party mission programme of the European Space Agency. The Atmospheric Chemistry Experiment (ACE) is a Canadian-led mission supported primarily by the CSA. The Aura satellite is flown and funded by the US National Aeronautics and Space Agency (NASA).

Edited by: Q. Errera

\section{References}

Adams, C., Bourassa, A. E., Bathgate, A. F., McLinden, C. A., Lloyd, N. D., Roth, C. Z., Llewellyn, E. J., Zawodny, J. M., Flittner, D. E., Manney, G. L., Daffer, W. H., and Degenstein, D. A.: Characterization of Odin-OSIRIS ozone profiles with the SAGE II dataset Atmos. Meas. Tech., 6, 1447-1459, doi:10.5194/amt6-1447-2013, 2013.

Adams, C., Bourassa, A. E., Sofieva, V., Froidevaux, L., McLinden, C. A., Hubert, D., Lambert, J.-C., Sioris, C. E., and Degenstein, D. A.: Assessment of Odin-OSIRIS ozone measurements from 2001 to the present using MLS, GOMOS, and ozonesondes, Atmos. Meas. Tech., 7, 49-64, doi:10.5194/amt-7-49-2014, 2014.

Andrews, D. G., Holton, J. R., and Conway, C. B.: Middle Atmosphere Dynamics, Academic Press Inc., 1987.

Bernath, P. F., McElroy, C. T., Abrams, M. C., Boone, C. D., Butler, M., Camy-Peyret, C., Carleer, M., Clerbaux, C., Coheur, P.-F., Colin, R., DeCola, P., DeMaziére, M., Drummond, J. R., Dufour, D., Evans, W. F. J., Fast, H., Fussen, D., Gilbert, K., Jen- nings, D. E., Llewellyn, E. J., Lowe, R. P., Mahieu, E., McConnell, J. C., McHugh, M., McLeod, S. D., Michaud, R., Midwinter, C., Nassar, R., Nichitiu, F., Nowlan, C., Rinsland, C. P., Rochon, Y. J., Rowlands, N., Semeniuk, K., Simon, P., Skelton, R., Sloan, J. J., Soucy, M.-A., Strong, K., Tremblay, P., Turnbull, D., Walker, K. A., Walkty, I., Wardle, D. A., Wehrle, V., Zander, R., and Zou, J.: Atmospheric Chemistry Experiment (ACE): Mission overview, Geophys. Res. Lett., 32, L15S01, doi:10.1029/2005GL022386, 2005.

Boone, C. D., Nassar, R., Walker, K. A., Rochon, Y., McLeod, S. D., Rinsland, C. P., and Bernath, P. F.: Retrievals for the atmospheric chemistry experiment Fourier-transform spectrometer, Appl. Opt., 44, 7218-7231, 2005.

Boone, C. D., Walker, K. A., and Bernath, P. F.: Version 3 Retrievals for the Atmospheric Chemistry Experiment Fourier Transform Spectrometer (ACE-FTS), The Atmospheric Chemistry Experiment ACE at 10: A Solar Occultation Anthology, edited by: Bernath, P. F., A. Deepak Publishing, Hampton, Virginia, USA, 103-127, 2013.

Brakebusch, M., Randall, C. E., Kinnison, D. E., Tilmes, S., Santee, M. L., and Manney, G. L.: Evaluation of Whole Atmosphere Community Climate Model simulations of ozone during Arctic winter 2004-2005, J. Geophys. Res., 118, 2673-2688, doi:10.1002/jgrd.50226, 2013.

Carslaw, K., Luo, B., and Peter, T.: An analytic expression for the composition of aqueous $\mathrm{HNO}_{3}-\mathrm{H}_{2} \mathrm{SO}_{4}$ stratospheric aerosols including gas phase removal of $\mathrm{HNO}_{3}$, Geophys. Res. Lett., 22, 1877-1880, 1995.

Considine, D. B., Douglass, A. R., Connell, P. S., Kinnison, D. E., and Rotman, D. A.: A polar stratospheric cloud parameterization for the global model initiative three-dimensional model and its response to stratospheric aircraft, J. Geophys. Res., 105, 39553973, 2000.

Dee, D. P. and Uppala, S. M.: Variational bias correction of satellite radiance data in the ERA-Interim reanalysis, Q. J. Roy. Meteorol. Soc., 135, 1830-1841, 2009.

Dee, D. P., Uppala, S. M., Simmons, A. J., Berrisford, P., Poli, P., Kobayashi, S., Andrae, U., Balmaseda, M. A., Balsamo, G., Bauer, P., Bechtold, P., Beljaars, A. C. M., van de Berg, I., Biblot, J., Bormann, N., Delsol, C., Dragani, R., Fuentes, M., Greer, A. J., Haimberger, L., Healy, S. B., Hersbach, H., Holm, E. V., Isaksen, L., Kallberg, P., Kohler, M., Matricardi, M., McNally, A. P., Mong-Sanz, B. M., Morcette, J.-J., Park, B.-K., Peubey, C., de Rosnay, P., Tavolato, C., Thepaut, J. N., and Vitart, F.: The ERA-Interim reanalysis: Configuration and performance of the data assimilation system, Q. J. Roy. Meteorol. Soc., 137, 553597, 2011.

Degenstein, D. A., Bourassa, A. E., Roth, C. Z., and Llewellyn, E. J.: Limb scatter ozone retrieval from 10 to $60 \mathrm{~km}$ using a multiplicative algebraic reconstruction technique, Atmos. Chem. Phys., 9, 6521-6529, doi:10.5194/acp-9-6521-2009, 2009.

De Mazière, M., Vigouroux, C., Bernath, P. F., Baron, P., Blumenstock, T., Boone, C., Brogniez, C., Catoire, V., Coffey, M., Duchatelet, P., Griffith, D., Hannigan, J., Kasai, Y., Kramer, I., Jones, N., Mahieu, E., Manney, G. L., Piccolo, C., Randall, C., Robert, C., Senten, C., Strong, K., Taylor, J., Tétard, C., Walker, K. A., and Wood, S.: Validation of ACE-FTS v2.2 methane profiles from the upper troposphere to the lower mesosphere, At- 
mos. Chem. Phys., 8, 2421-2435, doi:10.5194/acp-8-2421-2008, 2008.

Dupuy, E., Walker, K. A., Kar, J., Boone, C. D., McElroy, C. T., Bernath, P. F., Drummond, J. R., Skelton, R., McLeod, S. D., Hughes, R. C., Nowlan, C. R., Dufour, D. G., Zou, J., Nichitiu, F., Strong, K., Baron, P., Bevilacqua, R. M., Blumenstock, T., Bodeker, G. E., Borsdorff, T., Bourassa, A. E., Bovensmann, H., Boyd, I. S., Bracher, A., Brogniez, C., Burrows, J. P., Catoire, V., Ceccherini, S., Chabrillat, S., Christensen, T., Coffey, M. T., Cortesi, U., Davies, J., De Clercq, C., Degenstein, D. A., De Mazière, M., Demoulin, P., Dodion, J., Firanski, B., Fischer, H., Forbes, G., Froidevaux, L., Fussen, D., Gerard, P., GodinBeekmann, S., Goutail, F., Granville, J., Griffith, D., Haley, C. S., Hannigan, J. W., Höpfner, M., Jin, J. J., Jones, A., Jones, N. B., Jucks, K., Kagawa, A., Kasai, Y., Kerzenmacher, T. E., Kleinböhl, A., Klekociuk, A. R., Kramer, I., Küllmann, H., Kuttippurath, J., Kyrölä, E., Lambert, J.-C., Livesey, N. J., Llewellyn, E. J., Lloyd, N. D., Mahieu, E., Manney, G. L., Marshall, B. T., McConnell, J. C., McCormick, M. P., McDermid, I. S., McHugh, M., McLinden, C. A., Mellqvist, J., Mizutani, K., Murayama, Y., Murtagh, D. P., Oelhaf, H., Parrish, A., Petelina, S. V., Piccolo, C., Pommereau, J.-P., Randall, C. E., Robert, C., Roth, C., Schneider, M., Senten, C., Steck, T., Strandberg, A., Strawbridge, K. B., Sussmann, R., Swart, D. P. J., Tarasick, D. W., Taylor, J. R., Tétard, C., Thomason, L. W., Thompson, A. M., Tully, M. B., Urban, J., Vanhellemont, F., Vigouroux, C., von Clarmann, T., von der Gathen, P., von Savigny, C., Waters, J. W., Witte, J. C., Wolff, M., and Zawodny, J. M.: Validation of ozone measurements from the Atmospheric Chemistry Experiment (ACE), Atmos. Chem. Phys., 9, 287-343, doi:10.5194/acp-9-287-2009, 2009.

Fomichev, V. I., Jonsson, A. I., de Grandpré, J., Beagley, S. R., McLandress, C., Semeniuk, K., and Shepherd, T. G.: Response of the middle atmosphere to $\mathrm{CO}_{2}$ doubling: results from the Canadian Middle Atmosphere Model, J. Climate, 20, 1121-1144, doi:10.1175/JCLI4030.1, 2007.

Froidevaux, L., Jiang, Y. B., Lambert, A., Livesey, N. J., Read, W. G., Waters, J. W., Fuller, R. A., Marcy, T. P., Popp, P. J., Gao, R. S., Fahey, D. W., Jucks, K. W., Stachnik, R. A., Toon, G. C., Christensen, L. E., Webster, C. R., Bernath, P. F., Boone, C. D., Walker, K. A., Pumphrey, H. C., Harwood, R. S., Manney, G. L., Schwartz, M. J., Daffer, W. H., Drouin, B. J., Cofield, R. E., Cuddy, D. T., Jarnot, R. F., Knosp, B. W., Perun, V. S., Snyder, W. V., Stek, P. C., Thurstans, R. P., and Wagner, P. A.: Validation of Aura Microwave Limb Sounder $\mathrm{HCl}$ measurements, J. Geophys. Res., 113, D15S25, doi:10.1029/2007JD009025, 2008a.

Froidevaux, L., Jiang, Y., Lambert, A., Livesey, N., Read, W., Waters, J., Browell, E., Hair, J., Avery, M., McGee, T., Twigg, L., Sumnicht, G., Jucks, K., Margitan, J., Sen, B., Stachnik, R., Toon, G., Bernath, P., Boone, C., Walker, K., Filipiak, M., Harwood, R., Fuller, R., Manney, G., Schwartz, M., Daffer, W., Drouin, B., Cofield, R., Cuddy, D., Jarnot, R., Knosp, B., Perun, V., Snyder, W., Stek, P., Thurstans, R., and Wagner, P. A.: Validation of Aura Microwave Limb Sounder stratospheric ozone measurements, J. Geophys. Res., 113, D15S20, doi:10.1029/2007JD008771, 2008b.

Hegglin, M. I., Tegtmeier, S., Anderson, J., Froidevaux, L., Fuller, R., Funke, B., Jones, A., Lingenfelser, G., Lumpe, J., Pendlebury, D., Remsberg, E., Rozanov, A., Toohey, M., Urban, J., von Clar- mann, T., Walker, K. A., Wang, R., and Weigel, K.: SPARC Data Initiative: Comparison of water vapor climatologies from international satellite limb sounders, J. Geophys. Res., 118, 1182411846, doi:10.1002/jgrd.50752, 2013.

Hegglin, M. I., Plummer, D. A., Shepherd, T. G., Scinocca, J. F., Anderson, J., Froidevaux, L., Funke, B., Hurst, D., Rozanov, A., Urban, J., von Clarmann, T., Walker, K. A., Wang, H. J., Tegtmeier, S., and Weigel, K.: Vertical structure of stratospheric water vapour trends derived from merged satellite data, Nature Geosci., 7, 768-776, doi:10.1038/ngeo2236, 2014.

Jaeglé, L., Webster, C. R., May, R. D., Scott, D. C., Stimpfle, R. M., Kohn, D. W., Wennberg, P. O., Hanisco, T. F., Cohen, R. C., Proffitt, M. H., Kelly, K. K., Elkins, J., Baumgardner, D., Dye, J. E., Wilson, J. C., Pueschel, R. F., Chan, K. R., Salawitch, R. J., Tuck, A. F., Hovde, S. J., and Yung, Y. L.: Evolution and stoichiometry of heterogeneous processing in the Antarctic stratosphere, J. Geophys. Res., 102, 13235-13253, doi:10.1029/97JD00935, 1997.

Jimenez, C., Pumphrey, H. C., MacKenzie, I. A., Manney, G. L., Santee, M. L., Schwartz, M. J., Harwood, R. S., and Waters, J. W.: EOS MLS observations of dehydration in the 2004-2005 polar winters, Geophys. Res. Lett., 33, L16806, doi:10.1029/2006GL025926, 2006.

Lambert, A., Read, W. G., Livesey, N. J., Santee, M. L., Manney, G. L., Froidevaux, L., Wu, D. L., Schwartz, M. J., Pumphrey, H. C., Jimenez, C., Nedoluha, G. E., Cofield, R. E., Cuddy, D. T., Daffer, W. H., Drouin, B. J., Fuller, R. A., Jarnot, R. F., Knosp, B. W., Pickett, H. M., Perun, V. S., Snyder, W. V., Stek, P. C., Thurstans, R. P., Wagner, P. A., Waters, J. W., Jucks, K. W., Toon, G. C., Stachnik, R. A., Bernath, P. F., Boone, C. D., Walker, K. A., Urban, J., Murtagh, D., Elkins, J. W., and Atlas, E.: Validation of the Aura Microwave Limb Sounder middle atmosphere water vapor and nitrous oxide measurements, J. Geophys. Res., 112, D24S36, doi:10.1029/2007JD008724, 2007.

Livesey, N. J., Read, W. G., Froidevaux, L., Lambert, A., Manney, G. L., Pumphrey, H. C., Santee, M. L., Schwartz, M. J., Wang, S., Coeld, R. E., Cuddy, D. T., Fuller, R. A., Jarnot, R. F., Jiang, J. H., Knospa, B. W., Stek, P. C., Wagner, P. A., and Wu, D. L.: Earth Observing System (EOS) Aura Microwave Limb Sounder (MLS) Version 3.3 and 3.4 Level 2 data quality and description document, Tech. rep., JPL D-33509, 2013.

Llewellyn, E. J., Lloyd, N. D., Degenstein, D. A., Gattinger, R. L., Petelina, S. V., Bourassa, A. E., Wiensz, J. T., Ivanov, E. V., McDade, I. C., Solheim, B. H., McConnell, J. C., Haley, C. S., von Savigny, C., Sioris, C. E., McLinden, C. A., Griffioen, E., Kaminski, J., Evans, W. F. J., Puckrin, E., Strong, K., Wehrle, V., Hum, R. H., Kendall, D. J. W., Matsushita, J., Murtagh, D. P., Brohede, S., Stegman, J., Witt, G., Barnes, G., Payne, W. F., Piché, L., Smith, K., Warshaw, G., Deslauniers, D., Marchand, P., Richardson, E. H., King, R. A., Wevers, I., McCreath, W., Kyrölä, E., Oikarinen, L., Leppelmeier, G. W., Auvinen, H., Mégie, G., Hauchecorne, A., Lefévre, F., de La Nöe, J., Ricaud, P., Frisk, U., Sjoberg, F., von Schéele, F., and Nordh, L.: The OSIRIS instrument on the Odin spacecraft, Can. J. Phys., 82, 411-422, doi:10.1139/p04-005, 2004.

Mahieu, E., Duchatelet, P., Demoulin, P., Walker, K. A., Dupuy, E., Froidevaux, L., Randall, C., Catoire, V., Strong, K., Boone, C. D., Bernath, P. F., Blavier, J.-F., Blumenstock, T., Coffey, M., De Mazière, M., Griffith, D., Hannigan, J., Hase, F., Jones, N., Jucks, 
K. W., Kagawa, A., Kasai, Y., Mebarki, Y., Mikuteit, S., Nassar, R., Notholt, J., Rinsland, C. P., Robert, C., Schrems, O., Senten, C., Smale, D., Taylor, J., Tétard, C., Toon, G. C., Warneke, T., Wood, S. W., Zander, R., and Servais, C.: Validation of ACEFTS v2.2 measurements of $\mathrm{HCl}, \mathrm{HF}, \mathrm{CCl} 3 \mathrm{~F}$ and $\mathrm{CCl} 2 \mathrm{~F} 2$ using space-, balloon- and ground-based instrument observations, Atmos. Chem. Phys., 8, 6199-6221, doi:10.5194/acp-8-6199-2008, 2008.

Manney, G. L., Daffer, W. H., Zawodny, J. M., Bernath, P. F., Hoppel, K. W., Walker, K. A., Knosp, B. W., Boone, C., Remsberg, E. E., Santee, M. L., Harvey, V. L., Pawson, S., Jackson, D. R., Deaver, L., McElroy, C. T., McLinden, C. A., Drummond, J. R., Pumphrey, H. C., Lambert, A., Schwartz, M. J., Froidevaux, L., McLeod, S., Takacs, L. L., Suarez, M. J., Trepte, C. R., Cuddy, D. C., Livesey, N. J., Harwood, R. S., and Waters, J. W.: Solar occultation satellite data and derived meteorological products: Sampling issues and comparisons with Aura Microwave Limb Sounder, J. Geophys. Res., 112, D24S50, doi:10.1029/2007JD008709, 2007.

McLandress, C., Scinocca, J. F., Shepherd, T. G., Reader, M. C., and Manney, G. L.: Dynamical control of the mesosphere by orographic and nonorographic gravity wave drag during the extended northern winters of 2006 and 2009, J. Atmos. Sci., 70, 2152-2169, doi:10.1175/JAS-D-12-0297.1, 2013.

McLandress, C., Plummer, D. A., and Shepherd, T. G.: Technical Note: A simple procedure for removing temporal discontinuities in ERA-Interim upper stratospheric temperatures for use in nudged chemistry-climate model simulations, Atmos. Chem. Phys., 14, 1547-1555, doi:10.5194/acp-14-1547-2014, 2014.

Nezlin, Y., Rochon, Y. J., and Polavarapu, S.: Impact of tropospheric and stratospheric data assimilation on mesosphere prediction, Tellus, 61A, 154-159, 2009.

Peter, T.: Microphysics and heterogeneous chemistry of polar stratospheric clouds, Annu. Rev. Phys. Chem., 48, 785-822, 1997.

Rousseeuw, P. J. and Croux, C.: Alternatives to the Median Absolute Deviation, J. Amer. Stats. Assoc., 88, 1273-1283, 1993.

Santee, M. L., Lambert, A., Read, W., Livesey, N., Cofield, R., Cuddy, D., Daffer, W., Drouin, B., Froidevaux, L., Fuller, R., Jarnot, R., Knosp, B., Manney, G., Perun, V., Snyder, W., Stek, P., Thurstans, R., Wagner, P., Waters, J., Muscari, G., deZafra, R., Dibb, J., Fahey, D., Popp, P., Marcy, T., Jucks, K., Toon, G., Stachnik, R., Bernath, P., Boone, C., Walker, K., Urban, J., and Murtagh, D.: Validation of Aura Microwave Limb Sounder $\mathrm{HNO}_{3}$ Measurements, J. Geophys. Res., 112, D24S40, doi:10.1029/2007JD008721, 2007.

Santee, M. L., Lambert, A., Read, W., Livesey, N., Manney, G., Cofield, R., Cuddy, D., Daffer, W., Drouin, B., Froidevaux, L., Fuller, R., Jarnot, R., Knosp, B., Perun, V., Snyder, W., Stek, P., Thurstans, R., Wagner, P., Waters, J., Connor, B., Urban, J., Murtagh, D., Ricaud, P., Barrett, B., Kleinboehl, A., Kuttippurath, J., Kullmann, H., von Hobe, M., Toon, G., and Stachnik, R.: Validation of the Aura Microwave Limb Sounder ClO Measurements, J. Geophys. Res., 113, D15S22, doi:10.1029/2007JD008762, 2008a.

Santee, M. L., MacKenzie, I. A., Manney, G. L., Chipperfield, M. P., Bernath, P. F., Walker, K. A., Boone, C. D., Froidevaux, L., Livesey, N. J., and Waters, J. W.: A study of stratospheric chlorine partitioning based on new satellite measurements and modeling, J. Geophys. Res., 113, D12307, doi:10.1029/2007JD009057, 2008b.

Schwartz, M. J., Lambert, A., Manney, G. L., Read, W. G., Livesey, N. J., Froidevaux, L., Ao, C. O., Bernath, P. F., Boone, C. D., Cofield, R. E., Daffer, W. H., Drouin, B. J., Fetzer, E. J., Fuller, R. A., Jarnot, R. F., Jiang, J. H., Jiang, Y. B., Knosp, B. W., Kruger, K., Li, J.-L. F., Mlynczak, M. G., Pawson, S., Russell, J. M., Santee, M. L., Snyder, W. V., Stek, P. C., Thurstans, R. P., Tompkins, A. M., Wagner, P. A., Walker, K. A., Waters, J. W., and $\mathrm{Wu}, \mathrm{D}$. L.: Validation of the Aura Microwave Limb Sounder Temperature and Geopotential Height Measurements, J. Geophys. Res., 113, D15S11, doi:10.1029/2007JD008783, 2008.

Scinocca, J. F., McFarlane, N. A., Lazare, M., Li, J., and Plummer, D.: Technical Note: The CCCma third generation AGCM and its extension into the middle atmosphere, Atmos. Chem. Phys., 8, 7055-7074, doi:10.5194/acp-8-7055-2008, 2008.

Sheese, P. E., Llewellyn, E. J., Gattinger, R. L., Bourassa, A. E., Degenstein, D. A., Lloyd, N. D., and McDade, I. C.: Temperatures in the upper mesosphere and lower thermosphere from OSIRIS observation of $\mathrm{O}_{2}$ A-band emission spectra, Can. J. Phys., 88, 919-925, doi:10.1139/P10-093, 2010.

Sheese, P. E., McDade, I. C., Gattinger, R. L., and Llewellyn, E. J.: Atomic oxygen densities retrieved from Optical Spectrograph and Infrared Imaging System observations of $\mathrm{O}_{2} \mathrm{~A}$-band airglow emission in the mesosphere and lower thermosphere, J. Geophys. Res., 116, L11803, doi:10.1029/2010JD014640, 2011.

Sheese, P. E., Strong, K., Llewellyn, E. J., Gattinger, R. L., Russell III, J. M., Boone, C. D., Hervig, M. E., Sica, R. J., and Bandoro, J.: Assessment of the quality of OSIRIS mesospheric temperatures using satellite and ground-based measurements, Atmos. Meas. Tech., 5, 2993-3006, doi:10.5194/amt-5-2993-2012, 2012.

Shepherd, T. G., Plummer, D. A., Scinocca, J. F., Hegglin, M. I., Fioletov, V. E., Reader, M. C., Remsberg, E., von Clarmann, T., and Wang, H. J.: Reconciliation of halogen-induced ozone loss with the total-column ozone record, Nature Geosci., 7, 443-449, doi:10.1038/ngeo2155, 2014.

Sica, R. J., Izawa, M. R. M., Walker, K. A., Boone, C., Petelina, S. V., Argall, P. S., Bernath, P., Burns, G. B., Catoire, V., Collins, R. L., Daffer, W. H., De Clercq, C., Fan, Z. Y., Firanski, B. J., French, W. J. R., Gerard, P., Gerding, M., Granville, J., Innis, J. L., Keckhut, P., Kerzenmacher, T., Klekociuk, A. R., Kyrö, E., Lambert, J. C., Llewellyn, E. J., Manney, G. L., McDermid, I. S., Mizutani, K., Murayama, Y., Piccolo, C., Raspollini, P., Ridolfi, M., Robert, C., Steinbrecht, W., Strawbridge, K. B., Strong, K., Stübi, R., and Thurairajah, B.: Validation of the Atmospheric Chemistry Experiment (ACE) version 2.2 temperature using ground-based and space-borne measurements, Atmos. Chem. Phys., 8, 35-62, doi:10.5194/acp-8-35-2008, 2008.

SPARC CCMVal: SPARC Report on the evaluation of chemistryclimate models, vol. SPARC Report No. 5, WCRP-132, WMO/TD-No. 1526, edited by: Eyring, V., Shepherd, T. G., and Waugh, D. W., 2010.

Toohey, M. and von Clarmann, T.: Climatologies from satellite measurements: the impact of orbital sampling on the standard error of the mean, Atmos. Meas. Tech., 6, 937-948, doi:10.5194/amt6-937-2013, 2013. 
Waymark, C., Walker, K., Boone, C. D., and Bernath, P. F.: ACEFTS version 3.0 data set: validation and data processing update, Ann. Geophys., 56, 6339, doi:10.4401/ag-6339, 2013.

WMO (World Meteorological Organization): Scientific Assessment of Ozone Depletion: 2010, vol. Global Ozone Research and Monitoring Project - Report No. 52, Geneva, Switzerland, 2011. Wohltmann, I., Wegner, T., Müller, R., Lehmann, R., Rex, M., Manney, G. L., Santee, M. L., Bernath, P., Suminska-Ebersoldt, O., Stroh, F., von Hobe, M., Volk, C. M., Hösen, E., Ravegnani, F., Ulanovsky, A., and Yushkov, V.: Uncertainties in modelling heterogeneous chemistry and Arctic ozone depletion in the winter 2009/2010, Atmos. Chem. Phys., 13, 3909-3929, doi:10.5194/acp-13-3909-2013, 2013.
Wolff, M. A., Kerzenmacher, T., Strong, K., Walker, K. A., Toohey, M., Dupuy, E., Bernath, P. F., Boone, C. D., Brohede, S., Catoire, V., von Clarmann, T., Coffey, M., Daffer, W. H., De Mazière, M., Duchatelet, P., Glatthor, N., Griffith, D. W. T., Hannigan, J., Hase, F., Höpfner, M., Huret, N., Jones, N., Jucks, K., Kagawa, A., Kasai, Y., Kramer, I., Küllmann, H., Kuttippurath, J., Mahieu, E., Manney, G., McElroy, C. T., McLinden, C., Mébarki, Y., Mikuteit, S., Murtagh, D., Piccolo, C., Raspollini, P., Ridolfi, M., Ruhnke, R., Santee, M., Senten, C., Smale, D., Tétard, C., Urban, J., and Wood, S.: Validation of $\mathrm{HNO}_{3}, \mathrm{ClONO}_{2}$, and $\mathrm{N}_{2} \mathrm{O}_{5}$ from the Atmospheric Chemistry Experiment Fourier Transform Spectrometer (ACE-FTS), Atmos. Chem. Phys., 8, 3529-3562, doi:10.5194/acp-8-3529-2008, 2008. 